\title{
THE PHONEMES AND THE PHONOLOGICAL STRUCTURE OF THE YANGZHOU DIALECT
}

\author{
BY \\ VIBEKE BØRDAHL: \\ University of Arhus
}

\section{Introduction}

\subsection{Previous studies.}

Karlgren, B. : Etudes sur la Phonologie Chinoise. Archives d'études orientales, Vol, 15, 1-4. Paris 1915-24.

This work comprises 30 dialects, among which is the variant of Northern Chinese spoken in the town of Yangzhou. However, the data on the pronunciation of the Yangzhou dialect are not based on personal investigations, but on the dialect transcriptions of M. Parker, published in H. A. Giles: A Chinese English Dictionary, London 1918. Karlgren uses this material only with great care and scepticism. Besides the uncertainty of the source,

* This article is a revised version of an unpublished paper "Yangehou dialektens fonemer og fonologiske struktur" admitted for the degree of M. A. in 1969 at the University of Copenhagen.

\section{Acknowledgements}

My sincere thanks to Birte Nielsen, secretary at the Institute of East Aslan Studies, University of Arhus, for painstaking help with the translation work and typing of the manuscript; and to Mel-Yu Lo, who did the calligraphy in the most conscientious mammer. To my teachers and colleagues at the East Aslan Institute, University of Copenhagen, the East Asian Institute, University of Oslo, and the Centre de Linguistique Chinoise, Ecole Pratique des Hautes Etudes, Paris, I want to express my gratlude for good advice and stimulating discussions during my student years. Especially I feel hidebted to Professor Soren Egerod, who has kindly read my manuscript and made valuable corrections and suggestlons and whose guidance in Chinese linguistle studles has been extremely helpful. 
the dialect studies in Phonologie Chinoise were pursued in prephonemic days, the purpose of the study being the reconstruction of Ancient Chinese, and so we find no discussion of the phonological distinctions from a synchronic point of view.

Wang Nianfang: Yangzhou fangyan. Fangyan he putonghua congkan. Vol. II, Peking 1959.

Wang Shihua: Yangzhouhua yinxi. Kexue chubanshe, Peking 1959.

Hanyu fangyan cihui. Wenzi gaige chubanshe, Peking 1964.

Yuan Jiahua: Hanyu fangyan gaiyao. Peking 1960.

These descriptions present different phonetic transcriptions of the Yangzhou dialect, using the International Phonetic Alphabet (IPA). The transcriptions show certain discrepancies, but each of them seems consistent throughout. Bound variants are not reduced, free variants not described. But this follows as a logical consequence of the main purpose of these works, namely: To furnish a comparison between the Yangzhou dialect and the Peking dialect in order to serve as a guide to teachers of the common language (putonghua). In this situation it is more economical to use a transcription showing bound variants. Concerning the secondary purpose of these works, to furnish material for studies of Chinese historical linguistics, it is perhaps not the most useful kind of transcription. A more narrow transcription with a discussion of free variants might be better suited, sinec what is today's redundancies may very well have been yesterday's fundamentals. ${ }^{1}$ The studies of Wang Nianfang and Wang Shihua both include ample lists, giving the pronunciation of isolated 字 zi. Some of these are classified as colloquial (kouyu), sometimes not having any written character to represent the morpheme. Both works furnish detailed observations of the Yangzhou dialect, but the explicit discussion of the transeription chosen is focused on the comparison with the Peking dialect.

The aim of the present study is not comparative. The phono-

${ }^{1}$ Cf. Egerod, 1970 p. 71. 
logical system of the Yangzhou dialect is analysed and discussed from a synchronic phonemic point of view.

\subsection{Collection of data}

The data upon which this description is based, were collected from November 1967 to April 1968 in Paris. During that period I was studying at Centre de Linguistique Chinoise, Ecole Pratique des Hautes Eludes, under the direction of Alexis Rygaloff whom I should like to thank for his kind guidance. Chu Kya 'Tion (来家訓) worked together with me as informant and so I am very thankful for his indispensable help.

Mr. Chu was born in Yangzhou and lived there during childhood and youth, where he aquired middleschool education (揚州震旦中學), when nineteen years old, he left the town. Since then he has lived in Shandong, Anhui, Hebei, Hubei, Hunan, Jiangxi, Hongkong and finally - a couple of years before we met-in Paris. When we worked together he was 44 years old and working as a waiter in a Chinese restaurant. Most of his friends in Paris also came from Yangzhou and were using their mother tongue among themselves, as I often witnessed. Moreover, he spoke putonghua, but no foreign language.

The significance of the data collected is of course limited by the circumstances. I had no occasion to work with more than one informant, and we were not staying within the domain of the dialect. There was a risk of describing a very special idiolect with only limited validity for the dialect in general. However, my phonetic observations show a rather high similarity with the above mentioned deseriptions by Chinese linguists. The dissimilarities are-as far as I can see-owing not so much to the reality we are describing, as to the way we describe it. But perhaps the speech of $\mathrm{Mr}$. Chu was somewhat more influenced by putonghua forms than is usually the case in Yangzhou.

One part of the data consists of monologues spoken by Mr. Chu and recorded on tape. Among these, six are appended to the study in written form, namely a character version ${ }^{2}$ and a pho-

\footnotetext{
After the monologues were recorded on tape, the recordings were written down
} in Chmese characters by Mr. Chu, who was often rather annoyed with the colloquial 
nemic transcription. Furthermore, a translation of the monologues is supplied. Here Mr. Chu tells about his hometown and the local customs during his childhood. He relates some old myths and witty stories. The slyle is informal and repetitious with proverbs and sayings typical of people from Yangzhou interspersed.

The other part of the clata consists of an inventory of about 2,000 characters studied as suggested in Ding and Li: Hanyu fangyan diaocha jianbiao, Peking 1956. This part of the phonetic material generally corresponds well with the phonetic material of the monologues. No further sounds were found, but a good many further possible combinations of initials and finals were registered.

While collecting the data I have been conscious of the possible existence of different layers of pronunciation in the language, possibly congruent with speaking habits, contra reading habits, but not necessarily so. In the language of Mr. Chu I have found very little evidence of such different layer's of pronunciation. In the few cases where a word had two different prontmciations, both forms seem to fall easily within the limits of the phonetic and phonological structure of the rest of the vocabulary. These forms do not seem to break the general pattern of possible combinations of initials and finals.

There was, however, a tendency to let putonghua forms slip in among the genuine Yangzhou forms. This tendency was probably somewhat provoked by my presence, since I had to speak the Peking dialect. Whenever it was possible to make a clear sifting of the putonghua "slips of the tongue", these forms have not been considered. But in certain cases the situation was not that clear: it seems that the language of $\mathrm{Mr}$. Chu had developed in a direction of frec variation with certain putonghua forms. In cases where a clear distinction was impossible, the situation has been taken for granted and studied as such.

form he in this way had to follow when writing. In cases where a word didn't have any written representative, Mr. Chu would borrow another character. I am not quite sure according to what principle he would borrow, but he explained to me in which cases he had done so. These cases are marked $\square$ in the character version. 
1.3. Methodical preliminaries.

1.3.1. The syllable-morpheme and the commutation test.

The phonological investigation has been undertaken in the light of the theory that the syllable is a basic morphological and phonological unit in the Yangzhou dialect as woll as in other Chinese dialects. Certain marginal exceptions to this fundamental fact are not considered important enough to make the syllable invalid as a starting point in the phonological description of Chinese dialects. ${ }^{3}$

In order to find the distinctive features and smallest commutable segments, phonemes and tonemes, useful pairs for commutation have been tested. Because of the relatively independent status of the Chinese syllable-morpheme it has been most convenient to use this kind of unit for the commutation tests.

\subsubsection{The auditive and the structural syllable.}

During the first phases of the phonological analysis the auditive criterion, syllable peaks, was used to decide how many syllables a given piece of recorded speech would consist of. When asking my informant to repeat slowly a certain piece of his spcech, he would automatically repeat his utterance in a rather staccato form, where the number of sound parts would correspond to the syllable peaks, suggesting the limits of each syllable. This was a kind of "practical criterion". In later phases of the study, when the phonological structure of these postulated syllables was becoming clearer, it was evident that each of these syllables corresponded to one out of a few possible and very simple syllable structures. So it was confirmed that the postulated syllables were congruent with a very simply built phonological unit: the phonological syllable.

In Chinese dialects the syllable is very often defined as a sequence of speech sounds whose central, voiced element is the carrier of a limited number of tonal contours. But this definition,

\footnotetext{
${ }^{3}$ For a short discussion of the relationship between the concepts syllable, morpheme, word as relevant to modem Chinese cf. Kratochvil, 1968 p. 23-24.

4 more elaborate justification for this method of analysis is found in f.ex. Henne, 1964.
} 
of course, does not help to establish the limits of each syllable in a chain. Here the criterion of actual or potential pauses between the syllables is necessary. Also a study of juncture phenomena would be helpful. In the study of tones it is generally the frequency curves of the voiced part of the syllable that are described. However, besides the frequency curves typical of the different tone categories, intensity curves are perhaps just as fundamental for the perception of tones. ${ }^{5}$ Such intensity curves should in principle not be limited to the voiced part of the syllable, and if such curves could be established they might be very helpful in defining in a formal way not only the number of syllables in a given stream of speech, but also the limits of each syllable. ${ }^{6}$

\subsubsection{Syllable-constituents.}

The division of the Chinese syllable into two constituents, initial and final (with tone), immediately suggests itself also with regard to the Yangzhou dialect. The final and the tone can also be treated as separate constituents. The initial consists of the consonantic element or clements in the begimning of the syllable. The final comprises the rest of the segmental and semisegmental sounds of the syllable. The tone consists of the suprasegmental features of each syllable that enter into commutation. Actually, thcse so-called suprasegmental features also very often have certain kinds of segmental varieties, so that it may be possible to analyse the "tone" as part of the vowel and consonant system." The final with tone always comprises the central (syllableconstituting) element: in the Yangzhou dialect, always one central vowel or two central vowels in a balancing diphthong. ${ }^{8}$ The central element, however, sometimes manifests itself as a sort of vocalic prolongation of the previous initial consonant. ${ }^{9}$

S C. Kratochvil, 1971.

- In Kratochvil, 1968 chapter XI, 2. the tones of the Peking-dialects are discussed not only in terms of frequency curves, but also intensity curves. He, however, makes a cut in the intensity curve as well as the frequency curve every time a consonant-cven a voiced consonant-occurs. This seens to be rather inconsistent with the phonetic concept of intensity,

7 Cf. Chao, 1934 p. 41 and 44 ; cf. also Rygaloff, 1965 and Egerod, 1971.

8 Cf. p. 269.

${ }^{9}$ As for the similar phenomenon in the Peking dialect, cf. Chao, 1934 p. 43 and Hartimann, 1944 p. 31-32. 


\section{Phonetic materials}

The phonetic notation chosen is IPA supplemented by a few extra symbols where necessary. To illustrate the tone contours the system suggested by Y, R. Chao is used. ${ }^{10}$

\subsection{Initial consonantic units.}

Abbreviations :

lab. = labial, dent. = dental, alv. = alveolar, pal. = palatal, vel. $=$ velar, mod. $=$ modified, voic.$=$ voiced, asp. $=$ aspirated

[p'] unmod. unvoic. fortis asp. bilab, stop

[b] unmod, unvoic, lenis unasp. bilab. stop

[m] unmod. voiced unasp. bilab. nasal

[f] unmod, unvoic. labiodent, spirant

[N] labialized unvoic. labiodent. spirant

[t'] unmod. unvoic. fortis asp. apicoalv. slop

[d] unmod. unvoic. lenis unasp. apicoalv. stop

[n] unmod. voiced unasp, apicoalv. nasal

$\left[n_{j}\right]$ palatalized voiced unasp. dorsoalv. nasal

[1] unmod, voiced unasp. apicoalv. lateral

*ĩ] nasalized voiced unasp. apicoalv. lateral

$[\boldsymbol{\Lambda}]$ unmod. voiced unasp, dorsoalv. lateral

$*[\mathrm{r} \mathrm{l}]$ rolled voiced unasp. dorsoalv. lateral

$\left[\mathfrak{l}^{*}\right]$ affricated unvoic. fortis asp. apicoalv. stop

$\left[\mathrm{d}^{\mathrm{a}}\right]$ aflricated unvoic. lenis unasp. apicoalv. stop

[s] unmod. unvoic. apicoalv. spirant

[ $\left.\mathrm{c}^{\mathrm{s},}\right]$ africated unvoic. fortis asp. dorsopal. stop

$\left[e^{8}\right]$ affricated unvoic. lenis unasp. dorsopal. stop

[š] unmod. unvoic. dorsopal. spirant

[k'] unmod. unvoic. fortis asp. dorsovel. stop

$[\xi]$ unmod, unvoic. lenis unasp. dorsovel, stop

$*$ The symbols $[\tilde{i}]$ and $[\mathrm{r} l]$ have been created in order to illustrate the nasalized lateral $[\tilde{i}]$ and the rolled $\left.{ }_{r} 1\right]$ typical of the Yangzhou dialect. $^{11}$

\footnotetext{
${ }^{10}$ Chao, 1968 p. 25-26.

11 In the Yangzhou dialect we find that the nasal, lateral and rolled-lateral initials do not contrast with each other ef. p. 276.
}

17 Acta Orientalla, XXXVIII 


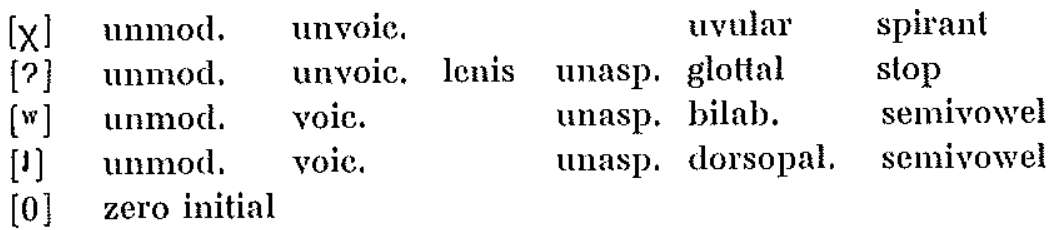

2.2. Final units.

$2.2,1$. Vowels.

Vowel nuances:

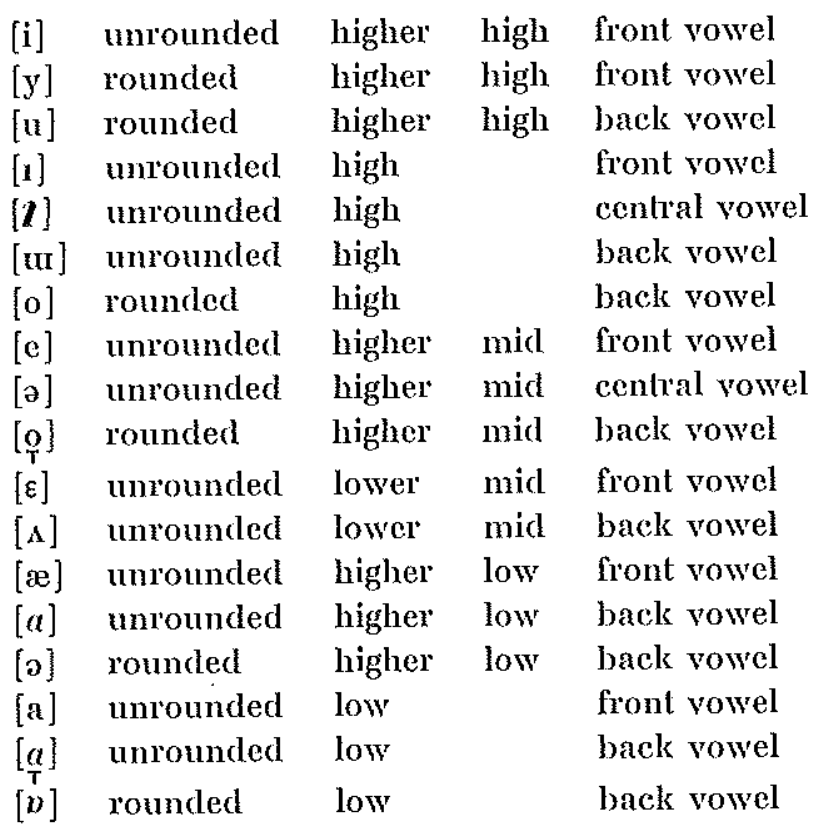

Vowel modifying factors:

Length :

[v:] i.e. long vowel

$\left[v^{*}\right]$ i.e. half-long vowel

[v] i.e. short vowel

Central

syllabic vowels ${ }^{12}$

\footnotetext{
12 No flnal has only one half-long vowel. Half-long vowels always occur in a balancing diphthong with another half-long vowel.
} 
[v] i.e. gliding short vowel

$$
\left\{\begin{array}{l}
\text { Marginal } \\
\text { nonsyllabic vowels }
\end{array}\right.
$$

Nasalization :

[ĩ ] i.e. nasalized vowel

cks. [ã:] i.e. long, nasalized, umrounded, higher low, back vowel.

2.2.2. Final consonants and semivowels.

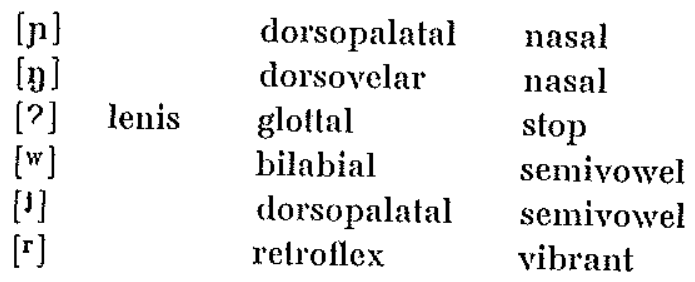

\subsubsection{Table I : Finals.}

Table I shows all combinations of final units that have been attested during the present investigation of the Yangzhou dialect. From this table it is apparent which units may be combined and in what way.

The finals are immediately arranged in certain groups:

(I) Long finals.

(II) Short finals.

a) Finals ending in glottal stop, called "glottal finals".

b) Finals with some nasal element, called "nasal finals".

c) Finals ending in $[\mathrm{F}]$.

i) Finals that don't belong to any of the previous groups.

i) Finals beginning with the vowels [i] or [r].

u) Finals beginning with the vowel [u].

y) Finals beginning with the vowel $[y]$.

Ø) Finals beginning with other vowels.

The symbol $=$ is used to show which finals variate freely, so that $\mathrm{X}=\mathrm{Y}$ means: $\mathrm{X}$ variates freely with $\mathrm{Y}$. 


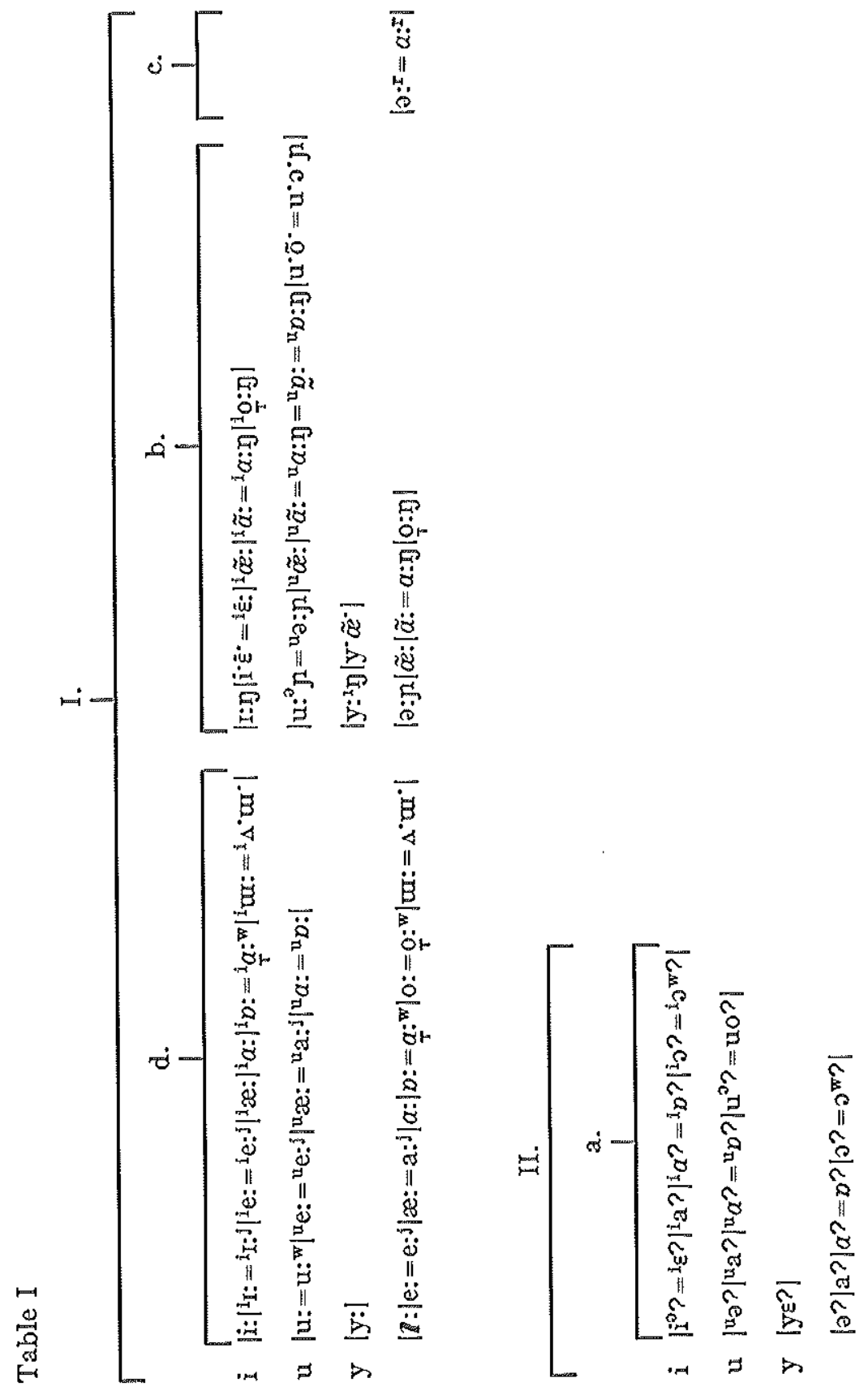




\subsection{5. 'Table II, III, IV and V.}

These tables show the attested combination possibilities of all finals with all initials. The symbol $x$ indicates that the combination is found in my Yangzhou material. ( $x$ ) indicates that the combination is rare and is found only in free variation with another form.

\subsection{Tones.}

Since tones, phonetically, are very much influenced by intonation and stress, it is very important to study these phenomena in such a way that the special tonal features can be extracted from the general intonation and stress patterns. In order to establish a theory of morphophonemic tone sandhi as well as neutralization of tone, one has to search for especially suitable cases of commutation. Otherwise, the whole complexity of phonetic and phonemic redundancy tends to obscure the question. The study of allophonic tone sandhi i.e. the phonetic variation of tones in accordance with the tonal surroundings and stress patterns, would have demanded better sound registering equipment and would also have been greatly improved, if several informants had been available.

In rapid or careless diction we observe the phenomenon that segmental sounds as well as tonal features may disappear to a point where certain phonemic oppositions can be said to be neutralized. This should not lead to confusion about the morphophonemic changes that occur in slow distinct diction and with a much higher degree of regularity. The neutral tone and morphophonemic sandhi should be observable when certain compound words or phrases with certain syntactic constructions are compared and tested for commutation. In these cases the negative influence of indistinct diction can be minimalized, while the actual phenomena of morphophonemic alterations can be obscrved, which is of course impossible when only single morphemes in citation form ${ }^{13}$ are studied. I have not been able to detect cases of commutation that would suggest morphophonemic tone sandhi

\footnotetext{
${ }^{13}$ Citation form: "an isolated language form uttered by a speaker outside any normal speech situation, usually for purposes of linguistic analysis". Kratochvil, 1968 p. 172.
} 


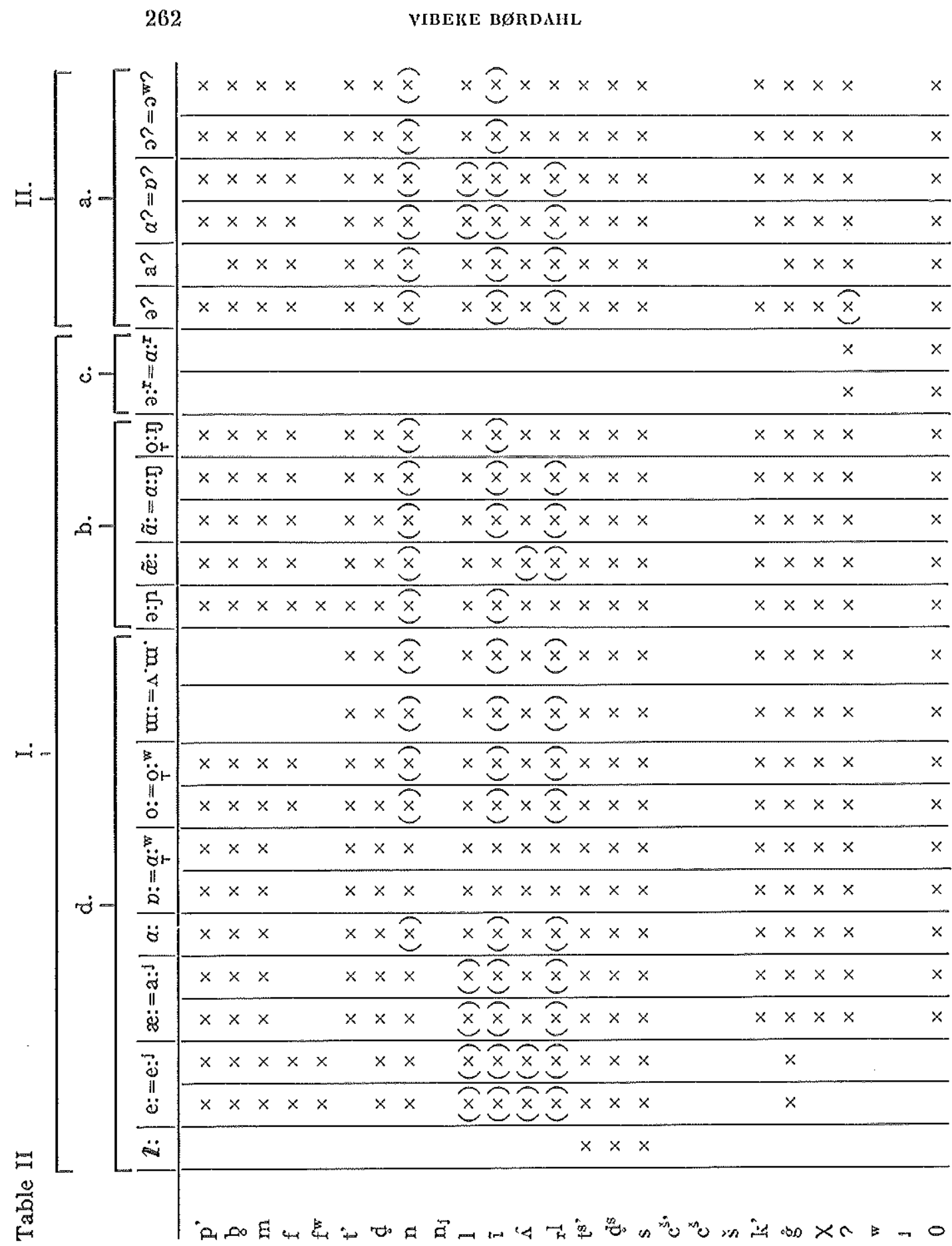


PHONEMES AND STRUCTURE OF THE YANGZIOU DILLCT 263

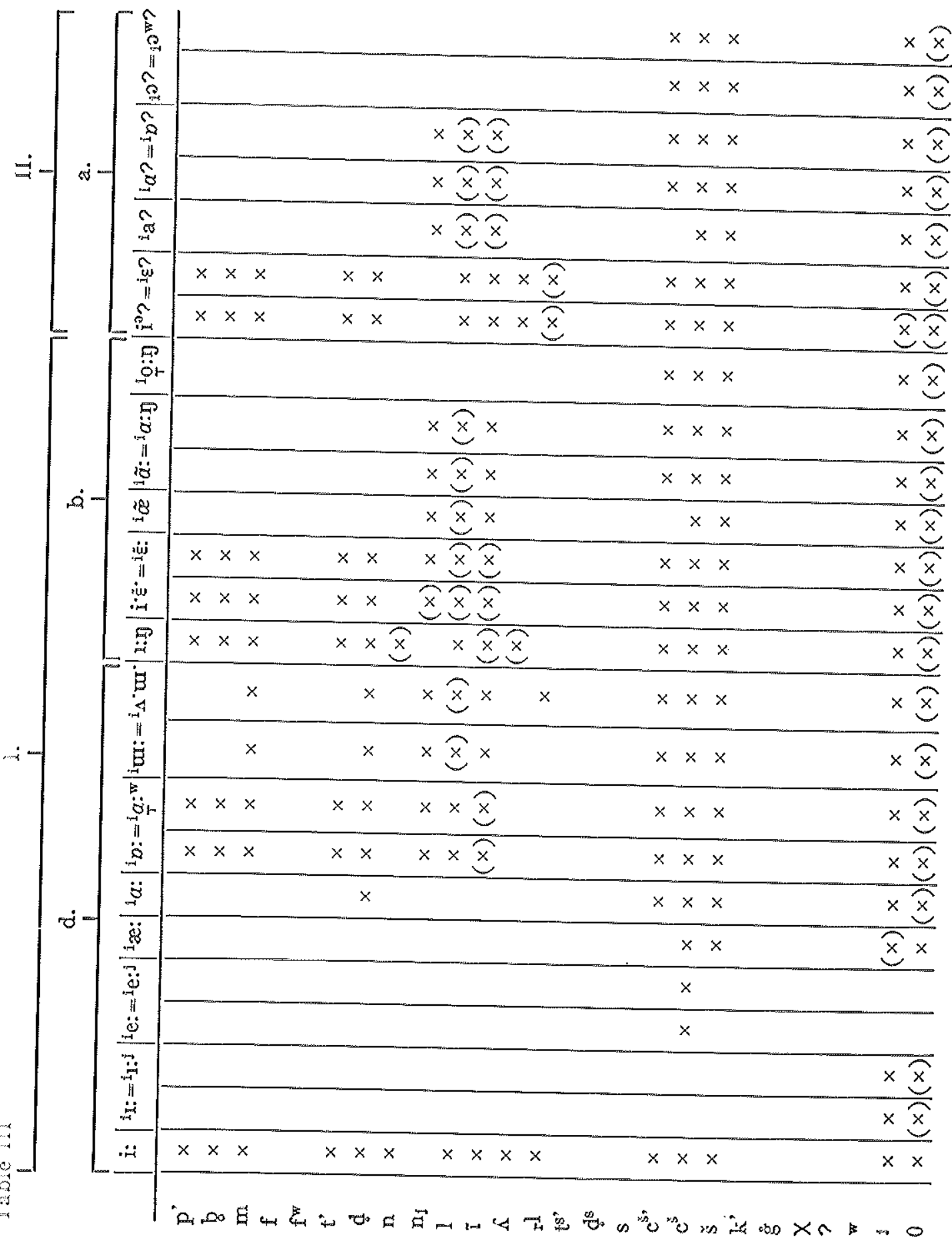




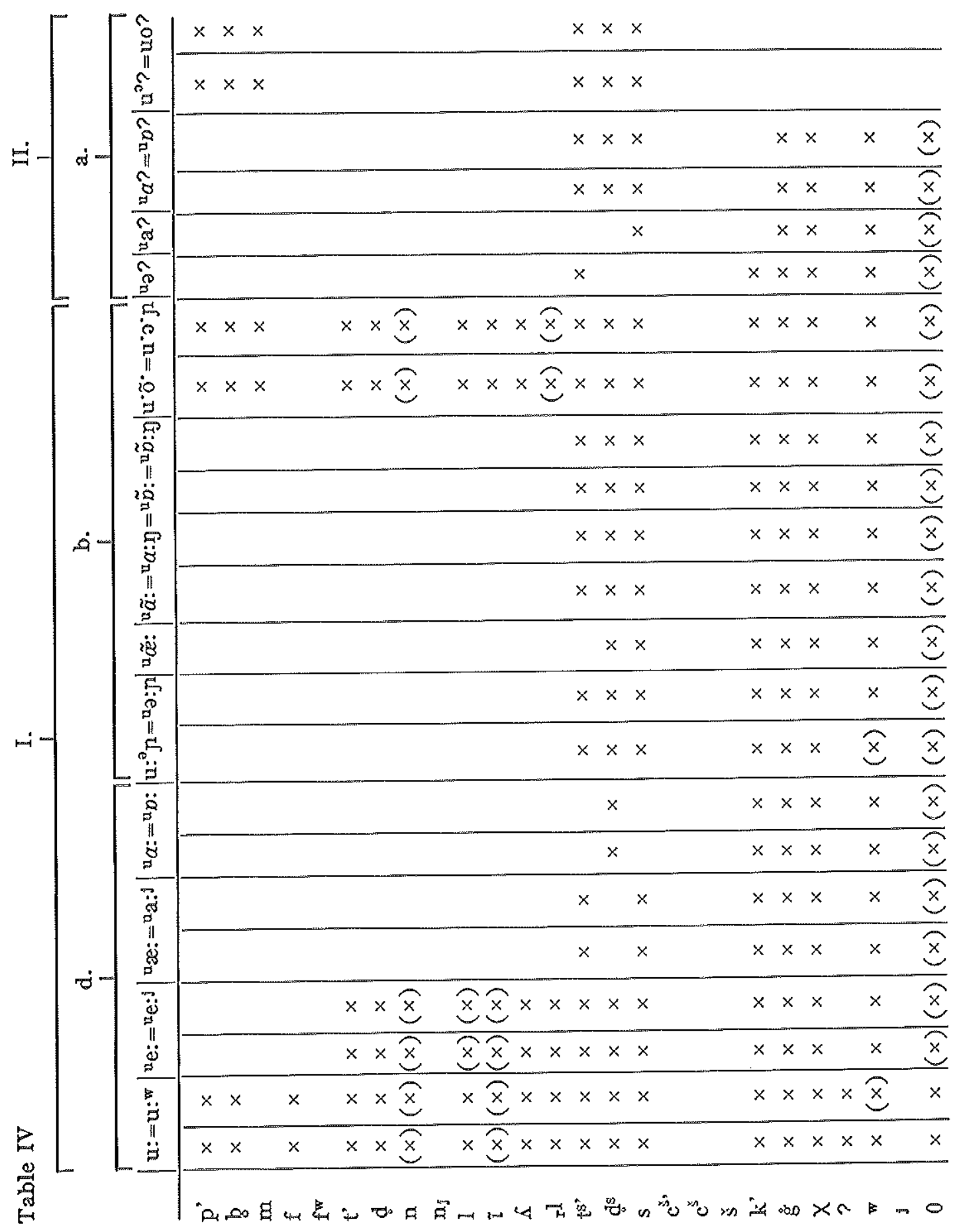


Table V
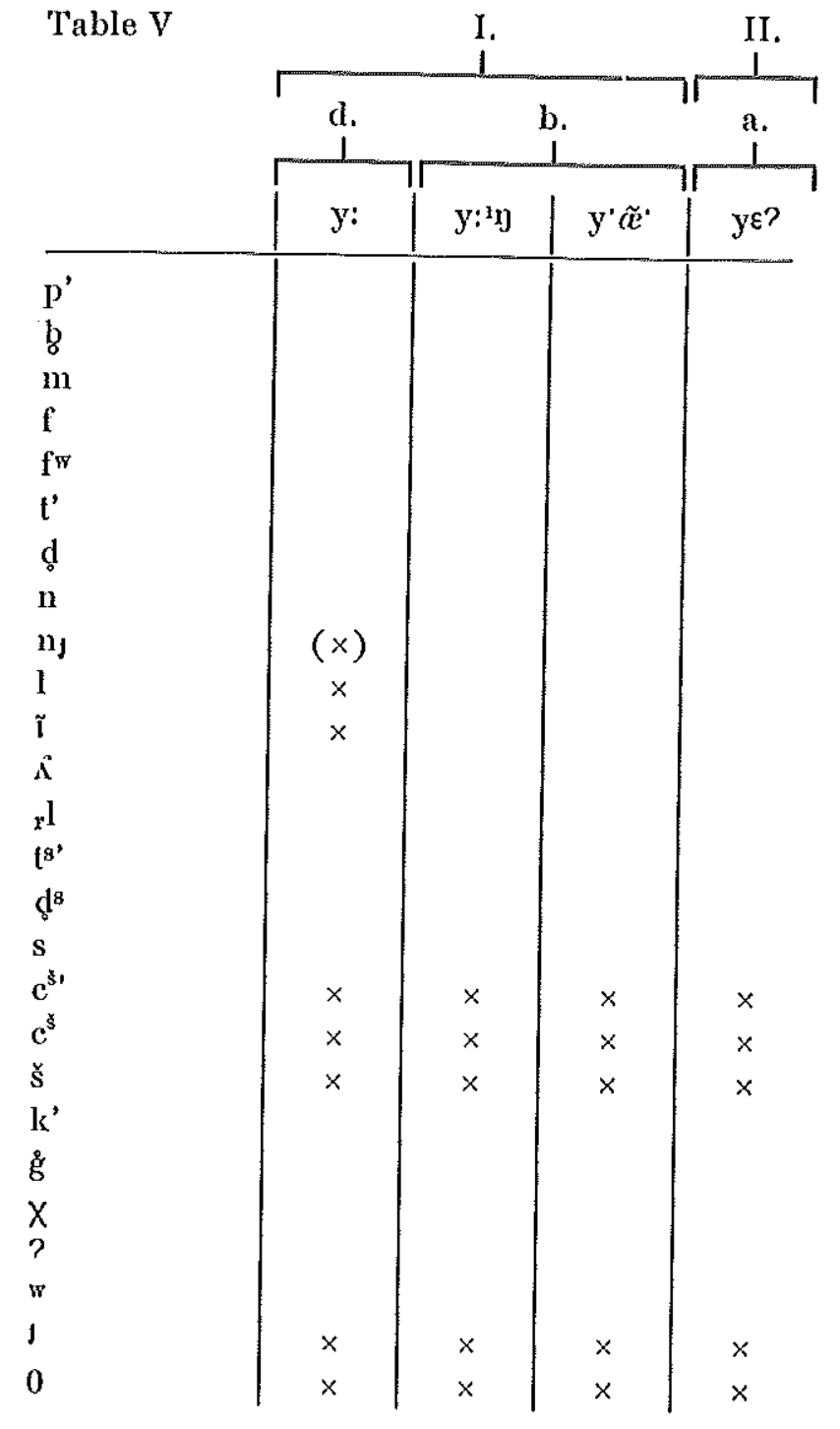

or real neutralisation of tone in the Yangzhou dialect, but possibly the corpus of vocabulary and phrases on which this study is based, has been too restricted to offer the necessary number of suitable pairs for commutation. In order to establish the tonemes of the Yangzhou dialect, the study has proceeded in three stages: 
1. The manifestation of tones in monosyllabic free words.

2. The manifestation of tones in monosyllabic bound morphemes in citation form.

3. The manifestation of tones in a) dissyllabic compound words and in b) phrases of varying syntactical construction.

The following results were obtaincd:

Morpheme-syllables with long finals could be divided in maximally four diflerent tone groups. 'The tone contours of these four groups was (in a one to five scale, as suggested by Y. R. Chao: ${ }^{14}$ )

$\begin{array}{lll}\text { Group I } & 21 & \text { J } \\ \text { Group II } & 24 & \text { A } \\ \text { Group III } & 31 & \checkmark \\ \text { Group IV } & 55 & 7\end{array}$

Morpheme-syllables with short finals could not be divided into further groups i.e. syllables with the same initial and the same short final could not be divided further into groups with mutual positive commutation. On the intonation scale they were manifested in a rather high pitch: 4 or $5 \%$

Examples of the tone groups within syllables with long final:

Group I

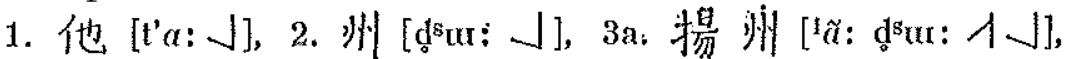
生活 [so:nX"o? ل才]，3b. 説書 [suo? su：" 1小], 都説 [du: suo? Jt]

Group II

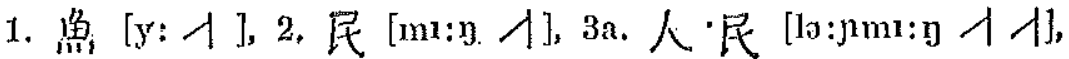

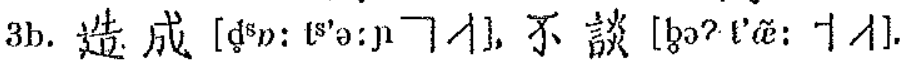

Group III

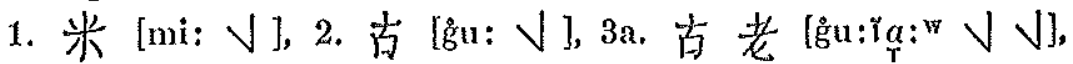

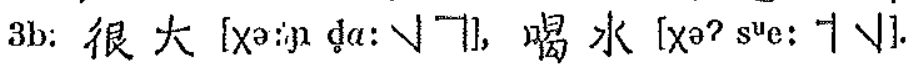

14 Cf. footnote (10). 


\section{Group IV}

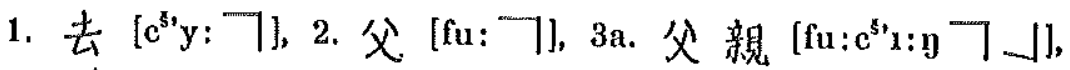

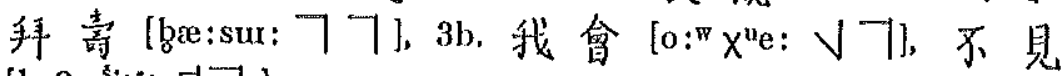
[ba? $\left.\left.\mathrm{c}^{\mathrm{s}} \mathrm{i} \cdot{ }^{*} \cdot \dagger\right\rceil\right]$ ].

Syllables with short final.

1. 不 [bo? 才], 2. 法 [fa? 才], 3a, 説洁 [suo? fa? 才 才], 3b.

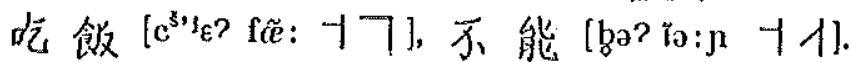

\subsection{Stress, juncture and intonation.}

No systematic description of these kinds of features will be attempted here. These phenomena have only been studied in an impressionistic way, and it is not improbable that some kind of phonemic stress might be found by further study and analysis.

In the phonemic transeription of the appended monologues, longer and shorter pauses as well as closed juncture between morphemes has been marked in quite an experimental way:

, i.e. half pause / i.e. full pause ${ }^{15}$

- i.e. closed juncture ex, 掦 州/ian-zw/

\section{Phonematic analysis}

The phonematic analysis is pursued on the basis of the three criteria: free variation, complementary distribution and phonetic similarily.

Possible reductions are described in four tempi:

1. Reductions of initials alone.

2. Reductions of finals alone.

3. Reductions of initials and finals.

4. Reductions of initials, finals and tones.

3.1. Initials.

[?] is in free variation with [0].

$[w]$ is in free variation with [0].

[j] is in free variation with [0].

\footnotetext{
${ }^{15} \mathrm{Cf}$. the appended monologues.
} 
[p'], [t'], [k'] can be analysed as clusters of two segmental elements i.e. [p] (unmodified, unvoiced, fortis, bilabial stop) + ['] (aspiration) and so on. Each of these segmental elements will then stand in complementary distribution with the corresponding nonaspirated lenis stops: [b], [d], [g] and the uvular spirant $[\mathrm{x}]$. In this way these initial sounds might be reduced to 4 phonemes: $/ \mathrm{p} /, / \mathrm{t} / \mathrm{,} / \mathrm{k} /$ and $/ \mathrm{h} /$, having the clusters $/ \mathrm{ph} /, / \mathrm{th} /, / \mathrm{kh} /$.

Likewise the initials $\left[\mathrm{ts}^{\mathrm{s}}\right],\left[\mathrm{d}^{\mathrm{s}}\right],\left[\mathrm{c}^{\mathrm{s} s}\right],\left[\mathrm{c}^{\mathrm{s}}\right]$ can be analysed as clusters of segmental elements such as $[t+8+'],\left[d+{ }^{8}\right],\left[c+t^{s}+'\right]$, $\left[c+{ }^{*}\right]$. These elements might then in accordance with their complementary distribution be identified with the above mentioned elements, so that the clusters are described as consisting of the following sequences of phonemes: $/ \mathrm{sh} /, / \mathrm{s} /, / \mathrm{cshh} /$, $|\mathrm{cš} /$.

This way of analysis and identification will result in a reduction in the number of symbols necessary to represent the initials, but on the other hand the description of the syllable structure becomes more complicated. It is a question how far and wide one wants to stretch the concept of phonetic similarity in identifying the elements, but a still more fundamental question is, whether one wants to obtain simplicity of description by an analysis into a smaller number of phonemic entities or by an analysis that results in comparatively fewer phonemic structure rules.

$\left[f^{*}\right]$ and $\left[n_{\jmath}\right]$ will be discussed in connection with the finals.

\subsection{Finals,}

While analysing the tones we usually make an abstraction from the fact that tones occur simultaneously with voiced consonants and vowels. In the same way I think that we can make an abstraction from the fact that such features as vowel length and nasalization of vowels also occur simultaneously with the vowels. In this way it becomes possible to deal with rowel length and nasalization apart, if it simplifies the description. It is of course necessary to keep constantly in mind the interdependency between the different kinds of phonetic features, so that one does not loose sight of important cases of complementarity.

When speaking of complementarity between the elements in the final, I mean that two elements have complementary distri- 
bution if they never occur with the same "rest" i.e. the final $\div$ the element concerned.

\subsubsection{Vowel length:}

Four different grades of vowel length are distinguished, cf. the list of final clements p. 258. It is possible to distinguish immediately between long and short finals. Both the long and the short finals may consist of diphthongs and triphthongs. Among these diphthongs and triphthongs it is relatively easy to distinguish descending, ascending or balancing relation between the vowels. ${ }^{16} \mathrm{By}$ using four different grades of vowel length this situation is accounted for:

\begin{tabular}{|c|c|c|}
\hline long finals & shor & \\
\hline$[\mathrm{v}:]$ & {$[\mathrm{v}]$} & monophthongs \\
\hline$\left[v^{*} v^{\prime}\right]$ & {$[\mathrm{vv}]$} & balancing diphthongs \\
\hline$[v: v]$ & {$\left[\mathrm{v}^{\mathrm{v}}\right]$} & descending diphthongs \\
\hline $\begin{array}{l}{\left[\mathrm{v}_{\mathrm{v}}:\right]} \\
{\left[\mathrm{v}_{\mathrm{y}^{\prime}} \mathrm{v}^{\prime}\right]}\end{array}$ & {$\left[v_{v}\right]$} & ascending diphthongs \\
\hline
\end{tabular}

The four grades of vowel length occur under the following conditions :

Central vowel $[\mathrm{v}]$ is only found in glottal final, either alone or in combination with another $[\mathrm{v}]$ or $[\mathrm{v}]$.

- $\quad\left[v^{*}\right]$ is not found in glottal final; is only found in combination with another $\left[\mathrm{v}^{*}\right]$, so that they together constitute a balancing diphthong. This diphthong may or may not be combined with $[\mathrm{v}]$ into a triphthong.

- $\quad[\mathrm{v}:]$ is not found in glottal final; is found either alone or in combination with [ $v$ ].

Marginal vowel [v] is only found in the finals in combination with one or several central vowels.

Different vowel length is never sufficient to differentiate two syllable-morphemes by a commutation test, it is never the only

${ }^{16}$ Cf. Flscher-Jorgensen, 1962 (1971), p. 96-97. 
distinctive feature. Therefore the question arises whether vowel length is a redundant phonetic phenomenon of secondary importance in the phonemic system.

Vowel length and glottal stop.

Before a conclusion is drawn it is necessary to consider the relationship between the glottal finals and finals with a short central vowel. There is in fact a relation of interdependence, so that the short central vowels occur only with the glottal finals and the long and half-long central vowels only with non-glottal finals. Actually the glottal stop is often very vaguely pronounced and hard to perceive in a stream of speech of normal rapidity. But one is not in doubt whether it is a short final or not. Instead of considering vowel length a redundant phenomenon, the glottalization could be considered redundant, and the contrast long versus short considered pertincnt.

Within the long finals and within the short finals the different vowel lengths are not distinctive. Consequently this phenomenon can be ignored in the further analysis of the vowels. Henceforth the short, glottal finals will be marked |'|. The long finals will not be especially marked.

Ex. | a' | i.c. short [a], or [a] followed by glottal stop, or short [a] followed by glottal stop.

Ex. | a | i.e. long [a], or non-glottal [a], or long non-glottal [a].

The final table after the above mentioned reductions: ${ }^{17}$

I. d.

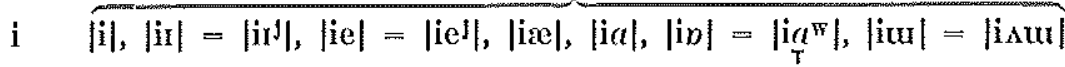

u $|u|=\left|u^{\mathrm{w}}\right|$, $|\mathrm{ue}|=|\mathrm{ue}|,|\mathrm{ure}|=|\mathrm{ua}|,|\mathrm{u} a|=|\mathrm{ub}|$

y $|y|$

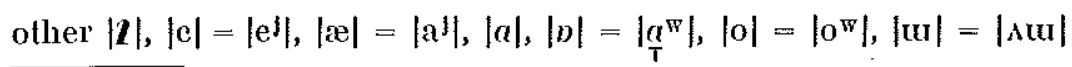

17 The finals $[i \cdot \tilde{\varepsilon} \cdot]$ and $\left[{ }^{i} \tilde{\varepsilon}:\right]$ are henceforth both written $|i \tilde{\varepsilon}|$, but since they occur in free variation nothing distinctive is lost. The same applies to the finals [u: $\left.{ }^{\circ}\right]$ and $\left[u_{0}: \mathrm{p}\right]$, written luojl. 
b.

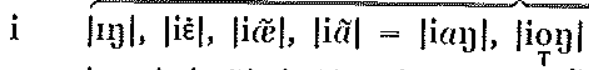

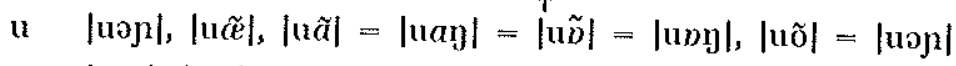

y $|\mathrm{y} y|,|\mathrm{y} \tilde{e}|$

other $\mid$ oj $|,| \tilde{e}|,| \tilde{a}|=| a \eta j|,| \mathrm{T} \mid$

c.

$\overbrace{\left|\partial^{\mathrm{r}}\right|=\left|a^{\mathrm{r}}\right|}^{\mathrm{cos}}$

II.

a.

i $\quad i^{\prime}|=| i \varepsilon^{\prime}||, i a^{\prime}||, i a^{\prime}|=| i b^{\prime}||, i 0^{\prime}|=| i 0^{\prime \prime} \mid$

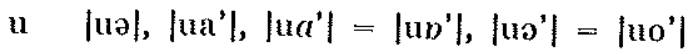

y |y's'|

other $\left|a^{\prime}\right|,\left|a^{\prime}\right|,\left|a^{\prime}\right|=\left|b^{\prime}\right|,\left|a^{\prime}\right|=\left|a^{\prime \prime}\right|$

\subsubsection{Nasals.}

Between the final nasal consonants $[\eta]$ and $[y]$ on the one hand and the nasalization $[\sim]$ on the other hand, there is partly free variation, partly complementarity. Free variation between $[\sim]$ and $[y]$ is found in following finals:

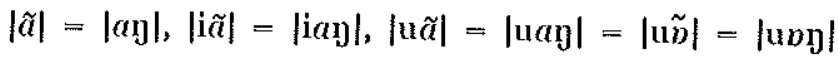

Complementary occurrence is found between $[\sim],[\mathrm{n}]$ and $[\mathrm{y}]$ in the rest of the nasal finals:

$[\sim]$ is found in the finals: $|i \bar{\varepsilon}|,|\tilde{e}|$, |i $\tilde{e}||, u \tilde{e}||, y \tilde{e}|| u o ̂ \mid$,

$[\mathrm{n}]$ is found in the finals: |ap|, |uop|, |uop|

$[y]$ is found in the finals: $|[y|,| \underset{T}{\mid}]|,|\underset{T}{\mid}|$

In other words, no examples have been found, where the different ways of manifestation of nasality in the final were distinctive. A positive result of the commutation test is dependent on a simultaneous difference in the vowel. It is therefore possible to reduce $[\sim],[\mathrm{j}]$ and $[\mathrm{y}]$ to one phonological unit, which could be written $-/ \mathrm{n} /$, although it is often manifested as nasalization of the central vowel.

Anolher solution is also possible: that is to consider the nasal 
consonants and the nasalization as separate phonological units, and try whether this leads to further reductions among the vowels, cf. p. 275 .

Nasals and glottal stop.

Between $[\sim],[n],[y]$ on the one hand and the glottal stop on the other hand there is actually complementary occurence. If a symbol / $/$ is used to mark the contrast long $<>$ short within the vowels, then the nasal elements and the glottal stop can be reduced to the same phonemic unit, symbolized by f.inst. $/ \mathrm{c} /$. When we have a long central vowel (ex, $a)+/ \mathrm{q} /$, this unit is phonetically manifested as one of the nasal elements (ex, $|a q|$ i.e. $[a: y]$ ). In cases of short central vowel $\left(e x .\left|a^{\prime}\right|\right)+/ \mathrm{q} /, / \mathrm{q} /$ is manifested as glottal stop, eventually faded to zero in rapid speech (ex. $\left|a^{\prime} \mathrm{q}\right|$ i.e. $[a ?])$. One of the principles for phonemic analysis and reduction is, however, hardly kept, since the phonetic similarity between the "bound variants" constifuting such a "phoneme" is very small, the only phonetic common denominator being the consonantic feature.

\subsubsection{Vowels and semivowels.}

All syllables ending in $[-1]$ or $[-w]$ have free variation with forms without such a semivowel in the ending, but often with either a more flat or a rounded central vowel (ex. [a:j] or [æ:] and $\left[a:^{w}\right]$ or $\left.[b:]\right)$. These finals can be analysed in two different ways:

A. The forms ending in $[-\mathrm{J}],[-\mathrm{w}]$ can be considered basic and the variant forms can be considered a diffusion of two latent phonemes.

B. The forms not ending in semivowel can be considered basic and the variant forms can be analysed as owing to a more gliding pronunciation of one phonological unit. The same is the case with the finals $|u|=|\Lambda u|$ and $|i u|=\mid i$ iu $\mid$. The right form can be considered basic (solution A.) or the left form (solution B.). 
If some of these final categories are handled according to solution $A$. and some according to solution B., it becomes possible to reduce the number of phonemes necessary to represent each final somewhat more, than if either of the solutions is followed throughout. Forms that are parallel from the phonetic viewpoint should however be analysed in a parallel way, especially when a strict synchronic analysis is attempted. Considerations of overall pattern for several dialects may lead to other conclusions, but this is beyond the scope of the present study.

Now the vowels will be analysed in order to find the cases of free variation and complementary distribution-first according to solution $A$., next according to solution $B$.

A.

Vowels.

We find free variation between $[\partial]$ and $[a]$ in the position [zero initial $-\mathbf{r}$ ].

Complementary distribution is found between :

[i] and [I]

[i] and [e]

$[e],[\varepsilon],[\partial]$ and $[\Lambda]$ except $[\partial]$ and $[\varepsilon]$ in the finals $\left|i \theta^{\prime}\right|=\left|i \varepsilon^{\prime}\right|$ which however have free variation (as shown

[æ] and [a] by the symbol $=$ )

$[a],[a]$ and $[b]$

except $[a]$ and $[b]$ in the finals $\left|a^{\prime}\right|=\left|b^{\prime}\right|,\left|i a^{\prime}\right|=\left|i v^{\prime}\right|,\left|u a^{\prime}\right|=\left|u b^{\prime}\right|$, $|\mathrm{u} \tilde{a}|=|\mathrm{u} \tilde{b}|=|\mathrm{u} a \eta|=|\mathrm{u} b \eta|$ which have free

$[\Lambda],[o], \underset{T}{\mathbf{o}}]$ and $[0]$ variation (as shown by the symbol $\Rightarrow$ )

[u] and [u]

([y] and [l] are not found in complementary distribution with any phonetically similar sounds).

These distributional relationships give the following possibilities of reducing the vowels:

18 Acta OHentalia, XXXVIII 


\section{A.a)}
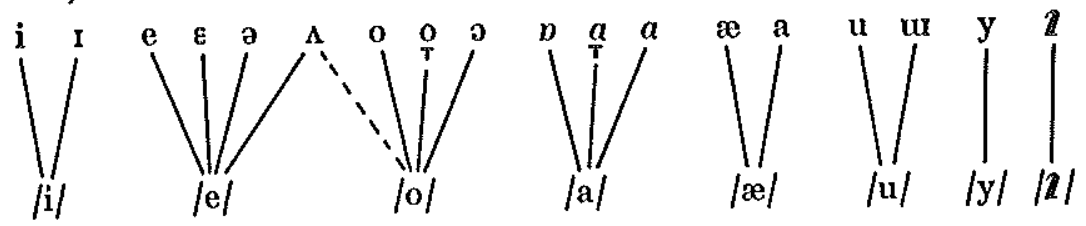

\section{A.b)}
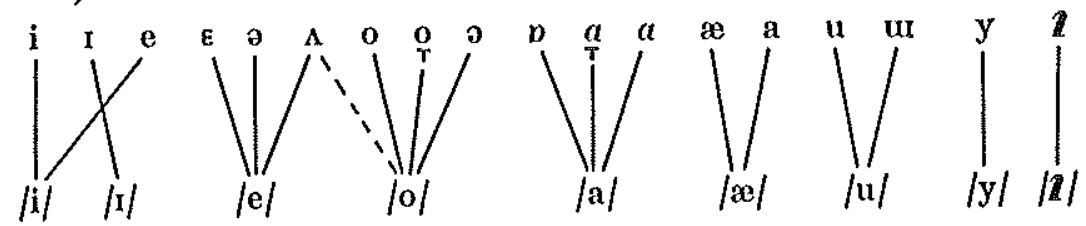

In solution a) as well as $b$ ) the phone $[\Lambda]$ can be attributed to either $/ \mathrm{e} /$ or $/ \mathrm{o} /$ as indicated by the stippled line. The latter alternative however implies that the semivowel [w] (cf. below) is prevented from being reduced together with [u] and [ur] into one phoneme $/ \mathrm{u} /$, because the contrast between the finals $\left[\Lambda^{\prime} u u^{\circ}\right] \rightarrow$ /ou/ and $[0: \mathbb{w}] \rightarrow / \mathrm{w} /$ or $/ \mathrm{ou} /$ would not be expressed in the latter case.

Semivowels and vowels.

Complementary distribution is found between the semivowel ['] and the vowels [i], [r] (a./i/) or [i], [e] (b./i/).

The reduction into one phoneme / $/$ / implies the writing/iii/ of the finals $\left[i_{e}: 1\right]$ or $\left[{ }_{1}: i\right]$, that is a sequence of three / $i /$ phonemes with the above phonetic manifestation (not a length indication).

[w] stands in complementary relationship to [u], [u] $(/ \mathrm{u} /)$. The reduction into one phoneme / $/$ / likewise implies writing / uu/ for the final $[\mathrm{u}: \mathrm{w}$ ] indicating a sequence of two $/ \mathrm{u} /$ phonemes.

Vowels, nasals and glottal stop.

If $[\sim],[n],[\eta]$ are considered one phoneme $-/ n /$, this does not change the complementary relationships among the vowels, which has just been described.

The further reduction of the nasals and the glottal stop into one phoneme $-/ \mathrm{q} /$ likewise does not change the complementary 
relationships among the vowels, but a phoneme // indicating short (versus long) duration is required in this case. The distributional relationships seem to indicate the possibility of reducing [a], [a] and [a] into one phoneme, if a distinction is kept between two nasal phonemes $/ \mathrm{n} /$ and $/ \mathrm{y} /([\sim]$ then has to be considered a variant of $/ \mathrm{n} / \mathrm{or} / \mathrm{y} /$ depending on the central vowel). However, since we find the finals |iæ|, |a'|, |ia'|, |ua'| in contrast to the finals $|\mathrm{i} a|,\left|a^{\prime}\right|,\left|\mathrm{i} a^{\prime}\right|,\left|\mathrm{u} a^{\prime}\right|$, we still have to keep these sounds as two separate phonemes $/ \mathrm{e} /$ and $/ \mathrm{a} /$.

B.

Vowels.

We find free variation between [ə] and [a] before [r].

Complementary distribution is found between:

[i] and $[\mathrm{I}]$

$[\mathrm{e}],[\varepsilon]$ and $[0]$ exeept $[\varepsilon]$ and $[0]$ in the finals $\left|i \varepsilon^{\prime}\right|=\left|\mathrm{i}^{\prime}\right|$, which [æ] and[a] have free variation (as shown by the symbol $=$ )

$[o],[0]$ and $[0]$ except $[0]$ and $[0]$ in the finals $\mid$ uo' $|=|$ uo|' which have free variation.

Free variation is found between $[a]$ and $[b]$ in the following finals :

$$
\begin{aligned}
& \left|a^{\prime}\right|=\left|b^{\prime}\right|,|\mathrm{u} a|=|\mathrm{u} b|,|\mathrm{u} \tilde{a}|=|\mathrm{u} \tilde{b}|=|\mathrm{u} a \mathrm{y}|=|\mathrm{u} b \mathrm{y}| \\
& \left|\mathrm{i} a^{\prime}\right|=\left|\mathrm{i} b^{\prime}\right| \\
& \left|\mathrm{u} a^{\prime}\right|=\left|\mathrm{u}^{\prime}\right|
\end{aligned}
$$

In other positions $[a]$ and $[p]$ contrast with each other. There can be said to exist a real syncretism between $[a]$ and $[b]$ in long finals beginning with [u] and in all short finals. I call this a real syncretism in the sense that we actually find free variation between the two sounds, opposite to what could be called a theoretical syncretism i.e. cases where only one of two (or more) phonetically rather similar phonemes can occur. (Concerning $[a]$ and $[b]$ such a theoretical syncretism exists in the finals $|a y|$ and $|\mathrm{i} a \mathrm{y}|$.

$[\mathrm{u}],[\mathrm{ur}],[\mathrm{y}]$ and $[\boldsymbol{I}]$ are not found in complementary relationship to any phonetically similar sounds. 
These distributional relationships give the following possibilities of reducing the vowels:

B.a)

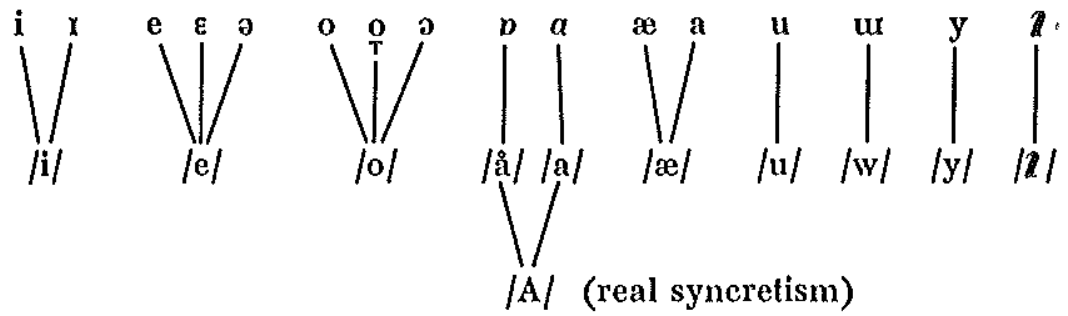

Vowels, nasals and glottal stop.

Using the B. analysis of the vowels, we obtain exactly the same relationships to nasals and glottal stop as those discussed under analysis $A$. No further reduction of the vowels seems possible.

\subsection{Initials and finals.}

\subsubsection{Initials.}

[f] and [fw] have free variation before the finals $[e:]=[e: 1]$ and $[\partial: n]$. Elsewhere $[f]$ is found.

$\left[n_{j}\right],[1],[i]$ have free variation before all finals beginning with [i] and $[y]$ except the final [i:].

$[\mathrm{n}],[\mathrm{l}],[\mathfrak{l}],[\hat{\Lambda}],[\mathrm{r} l]$ have free variation before all other finals, including the finals [i:] and [r:y].

Complementary distribution characterizes the apico-alveolar series $\left[\mathfrak{t}^{\prime}\right],\left[d^{\mathrm{s}}\right],[\mathrm{s}]$ vis-à-vis the dorso-palatal series $\left[\mathrm{c}^{\mathrm{s}^{*}}\right],\left[\mathrm{c}^{\mathrm{s}}\right],[\check{\mathrm{s}}]$.

$\left[c^{s}\right],\left[c^{3}\right],[\check{s}]$ is found only before finals that begin with [i], [1], [y].

$\left[\mathrm{s}^{\mathrm{s}}\right],\left[\mathrm{d}^{\mathrm{s}}\right],[\mathrm{s}]$ is found elsewhere.

Considering the distributional pattern of the initials we do however also find a complementary relationship between the dorso-velar/uvular series [k'], $[g],[X]$ vis-à-vis the dorso-palatal series $\left[c^{s ;}\right],\left[c^{s}\right]$, [ $\left.s\right]$. Here we run into problems wilh our phoneme definition. The interpretation of these facts is dependent on which of the phonetic features are considered pertinent. If the feature affication is considered pertinent, we may reduce the apicoalveolar series and the dorso-palatal series into one phoneme 
series. If the tongue position (here: dorsal) is considered the pertinent feature, then we have to reduce the palatal and velar (uvular) series into one phoneme series.

Bolh from a diachronic and a synchronic point of view there is basis for considering the palatal series a syncretism of the apico-alveolar and the velar-uvular series before $[i],[r]$ and $[y]$. From a synchronic point of view we may either use a notation indicating the palatal series as archiphonemes for the two other series, $^{18}$ or we may consider some phonetic features pertinent, others redundant, and reduce the palatal series together with one of the other series. This reduction can also be done arbitrarily without considering any features pertinent. ${ }^{10}$

While considering the palatal series a neutralization of the apico-alveolar and the velar-guttural series before [i], [I] and [y], I shall represent the series by the same symbols as the apicoalveolar series but in majuscule. 'This device is however dropped for the transcription of texts, where both series are written in minuscule.

Phonemic solutions

[p']

[b]

[m]

[f], [fw]

[l']

[d]

$[\mathrm{n}],\left[\mathrm{n}_{\mathfrak{s}}\right],[\mathrm{I}],[\mathrm{i}],[\hat{\mathrm{N}}],[\mathrm{r} \mathrm{l}]$

[ $\left.\mathbf{s}^{\mathrm{s}}\right]$

[d $\left.d^{\mathrm{s}}\right]$

[s]

$\left[\mathrm{c}^{\mathrm{s}}\right]$

$\left[c^{\mathrm{s}}\right]$

[క]

[k']

[s]

[X]

$[?],[\mathrm{w}],[\mathrm{H}],[0]$
A.

$\mid \mathrm{p} /$

/b/

/m/

|f|

$|\mathrm{t}|$

dal

/1/ or $/ \mathrm{n} /$

/cl

$|\mathrm{z}|$

/s/

/Cl

$|\mathrm{Z}|$

$\mid \mathrm{S} /$

$\mid \mathrm{k} /$

$|g|$

/b/

101
B.

$/ \mathrm{ph} /$

$\mid \mathrm{p} /$

/m/

|f |

/h/ $/$

/t/

/1/ or $/ \mathrm{n} /$

/ch/

/e/

|s/

/CH/

/C/

$|\mathrm{S}|$

/kh/

/k/

/h/

101 c.

/ph/

$|\mathrm{p}|$

/m/

|fi

th/

/II

/1/ or /n/

/tsh/

/ts/

$|\mathrm{s}|$

/TSH/

/TS/

|S|

/kh/

/k/

/h/

101

18 G. 'Trubetzkoy, 1958 p. 72.

10 This latter kind of procedure seems rathex forced, $\mathrm{Cf}$. f.ex. Bloch and Trager, 


\subsubsection{Finals.}

The final [ $\left.{ }^{\mathrm{e} e}\right]$ (which has free variation with $\left[{ }^{\mathrm{l} e} \mathrm{:}^{\mathrm{d}}\right]$ ) and the final $\left[{ }^{{ }} \mathrm{l}\right]$ (free variation with $\left[{ }^{1} \mathrm{r}^{\mathrm{d}}\right]$ ) have complementary distribution. The final [ $\left.{ }^{\mathrm{e}} \mathrm{e}\right] \mathrm{l}\left(=\left[\mathrm{e}^{\mathrm{d}}\right]\right)$ is found only after the initial $\left[c^{\mathrm{x}}\right]$; the final $\left[{ }_{\mathrm{I}}:\right]\left(=\left[{ }^{\mathrm{I}_{1}}:^{\mathrm{j}}\right]\right)$ only aftex $[\mathrm{J}]$ and [0]. This complementarity of $[1]$ and $[e]$ in the above finals suggest a further phonemic reduction within the vowels, splitting the phone [r] up into the two phonemes $/ \mathrm{i} /$ and $/ \mathrm{e} / \mathrm{.}$ This is necessary, because [ $\mathrm{i}$ ] in the final $[x: y]$ is only found after the palatal series $\left[c^{s^{*}}\right],\left[c^{s^{*}}\right]$ and $[\check{s}]$, not after the apico-alveolar or the velar/uvular series, so that [I] has to be considered a member of the phoneme /i/ in this position. In the few other finals where [ $\mathrm{I}$ ] is found it is then considered a member of the phoneme /e/. This solution has the advantage of giving more regularity in the distribution of phonemes in the finals and giving lesser possible vowel combinations. Moreover the sum of different finals possible is reduced.

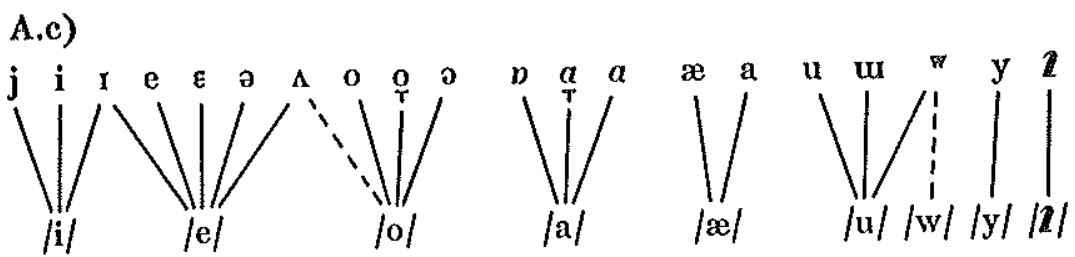

Since the alternative solution suggested by the stippled lines will add a phoneme $/ \mathrm{w} /$ to the system and doesn't offer any evident advantages, it will not be taken into consideration henceforth.

1942 p. 44. We get a "symbol-economy" which implles a good deal of understatement and only inadequately describes the phonological facts of the language. Here the simplicity and the necessity of the phoneme level in describing the plonological structure is questioned. This is actually a weak point in the phonemic theory, and the binary distmetive feature analysis with its "malrix-formulas" is in a certain sense more economical. But we are here balancing between at least two aims: that of giving a non-contradictory, exhaustive and simple description of the object of our study and that of presenting it to others in a readable way. Herein lies the weak point of the distinctive feature analysis. The symbol-economy of the phonemic analysis, where bundles of (distinctive) features are writtel with one or a few letters, still has large pedagogical advantages. 
PIIONEMES AND S'TRUCTURE OF THE YANgZhou DIALEGT 279

B.b)
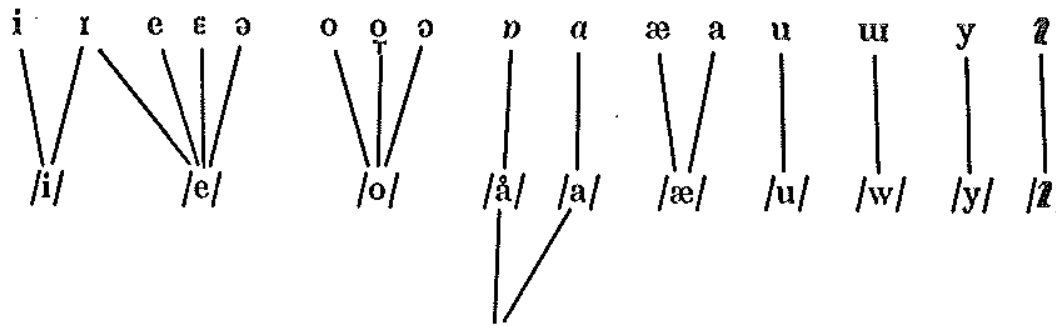

|A/ (real syncretism)

Vowel combinations of the different solutions:

A.

a)

ii)

/iii/

/iei/

/ia/

/ia/

/iau/

/ien/

/ie/

io/

|iou/

/uu/

/uei/

/uæi/

/ua/

/ue/

/uæ/

/uo/

$|y|$

/yi/

/yæ/

/ye/

|21

lei) b)

ii)

(iii)

/iii)

/ire/

|ia/

/iau/

/ieu/

/ie/

iol

/iou/

/uu/

/uii/

/uæi/

lual

/ue/

/ure/

$100 /$

|s/

|yi/

/ya/

/ye/

|a|

(ii) c)

ii)

|iei/

/ia/

/ia/

/iau/

/ieu/

/ie/

iio/

/iou/

/uu/

/uei/

/uæi/

|ual

/ue/

/ure/

/no/

$|y|$

|ye/

/ya/

|2)

lei)
B.

a) b)

/i)

/ii/

/ie/

/iæ/ /iæ/

ial $\quad$ ia

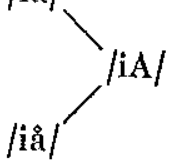

|ive

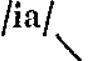<smiles>C[AlH2]</smiles>

/iw/

/io/ /io/

$|\mathrm{u} / \quad| \mathrm{u} /$

/ue/ /ne/

/uæ/ /uæ/

/uAl $/ \mathrm{uA} \mid$

/no/ /no/

$|y| \quad|y|$

$/ \mathrm{ye} / \mathrm{ye} /$

/yæ/ /yæ/

|2) $\quad 21$

/el $/ \mathrm{e} /$ 
A.

a) b)

/rei/ /ai/

/a $|a|$

/au/ /au/

lou/ lou/

/eu/ /eu/

|el |e/

/el $\mid \mathrm{re} /$

10/ $10 /$ c)

|aci|

|a|

/au/

lou/

/eu/

|el

$|x|$

1ol
B.

a) b)

/a/

/a/

$|a||a|$

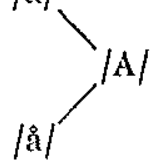

o/

$\mid a /$

$>_{\mid \mathrm{a} /}^{|\mathrm{A}|}$

1o/

$|\mathrm{w}|$

The finals $\left[o::^{\mathrm{r}}\right]$ and $\left[a:^{\mathrm{r}}\right]$, which vary freely, also vary with the final $[a:]$. But this variation is only found after zero initial (manifested as [?] or [0]) and only with certain morphemes.

\subsubsection{Identification of initial and final consonants.}

The final nasals may eventually be identified with the initial nasals and laterals as a phoneme $/ \mathrm{n} /$. Or, if the final nasals and the glottal stop are reduced to one phoneme (ef. p. 272) then we may identify this sound class with the initial lenis velar stop [ $g$ ] as one phoneme $/ \mathrm{g} /$. In this case we may further identify the final retroflex vibrant $[r]$ with the initial nasals and laterals (among which we also find a rolled variant $\left.\left[{ }_{1} 1\right]\right)$. The symbol /1/ could appropriately be chosen to represent such a sound class.

\subsubsection{The minimal final.}

The final $[2:]$ is found only after the initials $\left[t^{\prime}\right],\left[d^{s}\right],[s]$. This very special vowel can be considered the voiced, syllabic continuant of the preceding consonant ${ }^{20}$, i.e. a neutral vowel phoneme, which might be represented by the symbol $/ \% /$ or a letter indicating the minimal syllable forming status. I shall choose the letter $/ \sigma /$

\footnotetext{
${ }^{20} \mathrm{Cf}$. Hartmann, 1944 p. 32 , with a view to his analysis and phonemic solution for the Peking dialect, where we find the same phenomenon: ". . . These finals are minimal. Their principal characteristic property is syllabicity, while their qualities are conditioned by the preceding consonants."
} 
to present this phoneme, since that letter is often associated with the meaning zero.

\subsection{Inilials, finals and tones.}

3.4.1. Syllables with long final.

Not all syllables with long final have been found with all the four distinctive tonal contours: [21], [24], [31] and [55]. But the occurrence seems arbitrary; in any case no pattern of occurrence has been observed, and so no further reductions are suggested by the distribution of tones vis-à-vis the initials and finals. The distribution of the tones over the morpheme-syllables correspond with a number of exceptions to the distribution of the four tones of the Peking dialect as shown below:

Peking: 1. tone (阴平) 2. tone (阳平) 3. tone (上声) Yangzhou: [21] [24] [31]

Peking: 4. tone (去声)

Yangzhou: [55]

The tones will be presented by diacrities as follows:

$$
[21] \%, \quad[24] \%, \quad[31] \%, \quad[55] \%
$$

\subsubsection{Syllables with short final.}

Do syllables with short final have tone and if so what kind? The problem can be viewed in three ways:

a) Morpheme-syllables with short final don't have tone, but the shortmess and glottal ending are special features characterising these finals and analysed as constituting a segmental phoneme /\%.

b) Morpheme-syllables with short final are manifested in the high level of the frequency scale and so have more similarity with the fourth tone 55 than with any other of the four tones characterising the syllables with long finals. We might therefore consider the case a bound variant of the fourth tone. ${ }^{21}$

a1 Wang Shihua, 1959, gives the following discription of the tones:

$$
\text { 阴平阳平上声去声入声 }
$$

[11] [35] [42] [55] [4]


c) Morpheme-syllables with short final have a fifth tone, because shortness itself is considered a tonal feature in this system. If this solution is chosen the element shortness and the lenis glottal stop characteristic of these finals may all be reduced into one semi-tone phoneme // written after the vowel.

\section{Cholce of phonemic solution for transcription}

\subsection{Initials.}

The solution A. (p. 277) is chosen to represent the initials. From a diachronic and comparative point of view this choice would seem to have certain shortcomings, since it does not fit earlier conventions for an overall pattern too well (f.ex. b, d, g are used to represent the unvoiced, unaspirated stops, in spite of the fact that a voiced series is reconstructed for earlier stages and is still found in certain modern dialects). But an overall pattern between different dialects with regard to phonemes is in my opinion not really possible. Such an overall pattern should be handled on another level, such as that of the distinctive features. In this article material for the comparative study of the dialects is offered mainly in the phonetic part. Here in the choice of a phonemic solution I shall try to provide the simplest account of the phonological structure which is at the same time in best accordance with the phonetic data.

Solution A. seems better in accordance with the homorganic nature of all the initials, and also when syllable structure is considered, offers possibility for a simpler description than the more "sound-splitting" and symbol-economic solutions.

$/ 1 /$ is chosen rather than $/ \mathrm{n} /$, since lateral and lateral-flavoured sounds have a statistic preponderance, ef. also p. 283-84. The neutralization phonemes written in majuscule in the phonological description, will be written in minuscule in the transcription of texts.

He further notes that $\perp$ f $\mathcal{F}^{ \pm}$has the sandhi form [4], so that it resembles the $\lambda$ 声 in this form. From this description it would be more natural to consider $入$ 声 a bound variant of $上$. 


\subsection{Finals.}

\subsubsection{Vowels.}

The solutions A.c) and B.b) (p. 278-79) are the simplest.

A.c) has 8 different vowels: 7 monophthongs, 16 diphthongs and 6 triphthongs.

B.b) has 10 different vowels, among which two often have real syncretism: 10 monophthongs and 12 diphthongs.

Neither of these solutions can be considered decidedly simpler than the other.

B.b) is chosen, since the free variants upon which this solution is based, have a statistical preponderance. The neutralization of certain phonemes in certain positions written in majuscule in the description, is written in minuscule in the transcription of texts.

$[\boldsymbol{l}]$ is written $/ \sigma /$ as mentioned (p. 280).

\subsubsection{Nasals, glottal stop and [r].}

Among the different solutions proposed we obtain the most symbol-economic result by reducing all nasals to $/ \mathrm{n} /$, identifying this final nasal phoneme with the initial nasals and laterals, further identifying the glottal stop with the initial $[g]$ as the phoneme $\mid \mathrm{g} /$, and establish a phoneme $/ \mathrm{r} /$ for the final ending $\left[{ }^{\mathrm{r}}\right]$. But $\mathrm{I}$ consider this kind of phonemicizing too drastic. The relationship to the phonetic data is too complicated. We have a complementary distribution which allows this kind of reduction, and we might build our argument for doing so by stressing that the similarity between the units identitied as phonemes in this way is bigger than between any other final and initial sound units. I shall however prefer to stress the difference that does exist between these "identifiable" units, namely that their relationships in the paradigm of sound units are quite unsimilar: Initial $/ \mathrm{n} /$ and $/ \mathrm{g} /$ contrast with the whole long series of initial consonants. Final $/ \mathrm{n} /$ and $/ g /$ only contrast with each other and $/ \mathrm{r} /$. Initial $/ \mathrm{n} /$ and $/ g /$ imply very little about the following vowels. Final $/ \mathrm{n} /$ and $/ g /$ imply a lot about the possible vowels of the final. In other words, there is a tight relationship of interdependence between the vowels of the final and the final consonantic units, whereas the relationship between the initial consonants and the vowels is much looser. 
I should therefore prefer a less symbol-economic solution stressing the difference between the final and initial sound units rather than the very scanty similarity.

The nasals are reduced to $/ \mathrm{n} /$ (The initial nasals and laterals are witten $/ 1 /)$.

The short, glottal finals are finished by the phoneme //, f,ex. $\mid a^{\prime} /\left(\left[a^{2}\right]\right)$, indicating the short abrupt manifestation which is the most typical feature of these finals. It is at the same time an indication of "the 5th tone" which is reduced together with the elements "shortness" and "glottal ending" into one phoneme $/ 1$.

$[r]$ has then to be established as a separate phoneme $/ r /$ with very rare occurrence.

\subsection{Tones.}

The accent marks $/ \%, \%, \%, /$ are used as a transcription of the tone phonemes cf. p. 281. "The "5th tone" which has an intermediate status (like the final nasals) between the segmental and the suprasegmental elements is written // as mentioned.

4.4. The adopted phonemic transcription.

Initials :

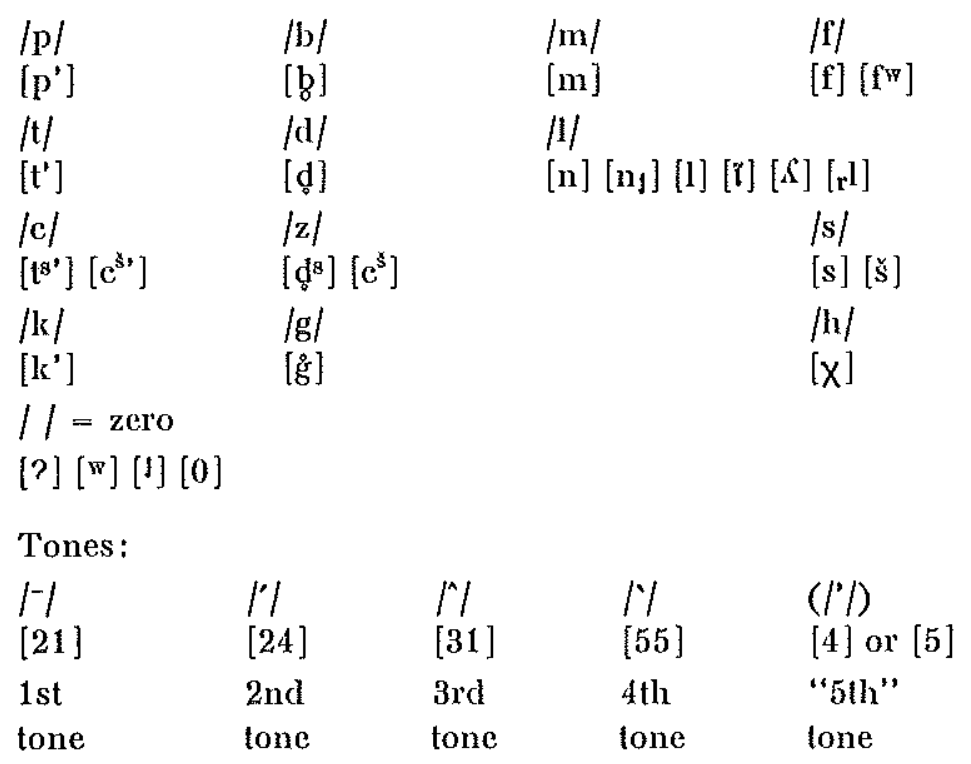


Finals :

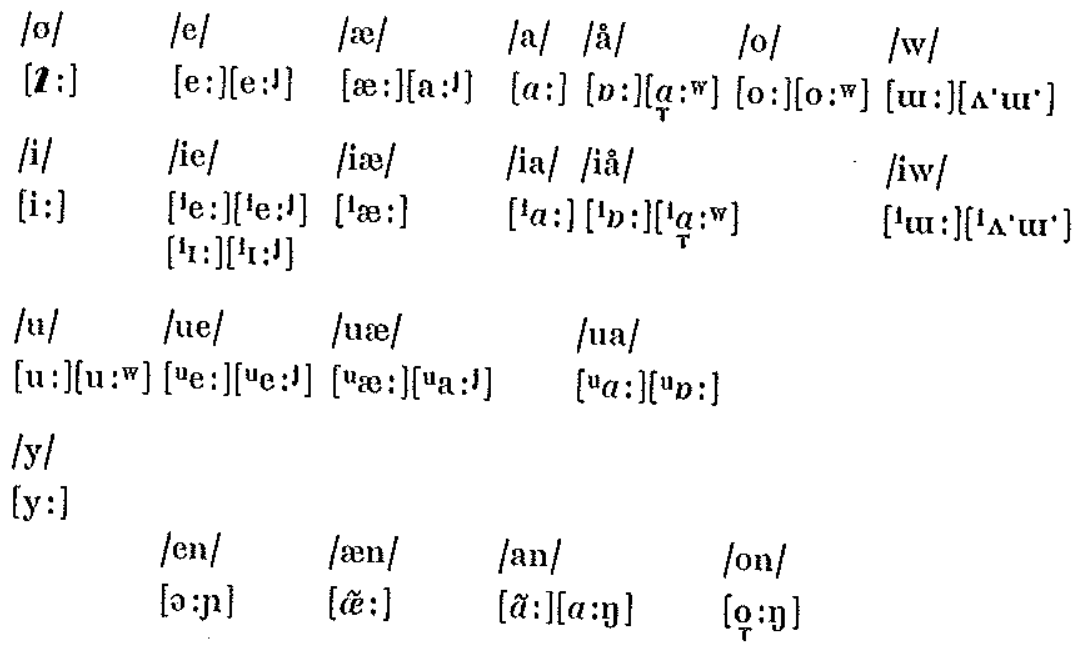

/in/ /ien/ /iæn/ /ian/ /ion/

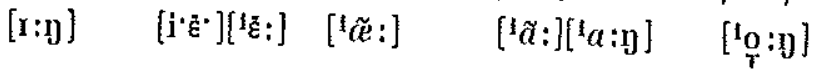

/uen/ /uan/ /uan/ /tuon/

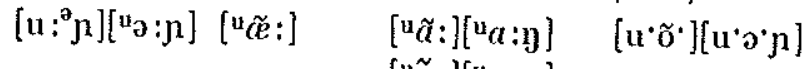

/yen/ /yæen/

$\left[{ }^{u} \tilde{b}:\right]\left[{ }^{u} p: \eta\right]$

$\left[\mathrm{y}:{ }^{1} \mathrm{y}\right] \quad\left[\mathrm{y}^{\prime} \tilde{\mathrm{e}}^{*}\right]$

\begin{tabular}{|c|c|c|c|}
\hline $\begin{array}{l}\mid \mathrm{er} / \\
{[0: \mathrm{r}]}\end{array}$ & & $\begin{array}{l}\mid a r / \\
{\left[a:^{r}\right]}\end{array}$ & \\
\hline$|\mathrm{e} '|$ & $\left|a e^{\prime}\right|$ & $\left|a^{\prime}\right|$ & $10 \%$ \\
\hline [ə?] & [a?] & {$[a ?]\left[p^{?}\right]$} & {$\left[0^{2}\right]\left[0^{w} ?\right]$} \\
\hline $\mid \mathrm{ie} /$ & /iæ'/ & $\left|\mathrm{ia}^{\prime}\right|$ & $\left|\mathrm{io}^{\prime}\right|$ \\
\hline$\left[i^{3} P\right]\left[{ }^{1} \varepsilon ?\right]$ & {$\left[l_{a} ?\right]$} & {$\left[l^{t} a ?\right]\left[\left[_{b} ?\right]\right.$} & {$[\mathrm{\rho} ?]\left[\left[^{\circ} \mathrm{v} ?\right]\right.$} \\
\hline /ue'/ & /uæ'/ & |ar'| & $\left|110^{\prime}\right|$ \\
\hline$[$ [ัว?] & {$\left[\mathrm{u}_{\mathrm{a}} \mathrm{P}\right]$} & {$\left[{ }^{u} a ?\right]\left[u_{p} ?\right]$} & {$[\mathrm{uo} ?]\left[\mathrm{u}^{\mathrm{o}} \mathrm{r}\right]$} \\
\hline
\end{tabular}


Examples of the registered initial and final combinations.

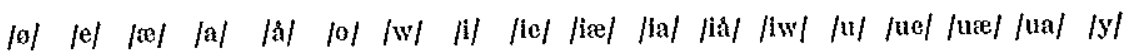

\begin{tabular}{|c|c|c|c|c|c|c|c|c|c|c|c|c|c|c|c|c|c|c|}
\hline $\mid \mathrm{p} /$ & & 陪 & 牌 & 怕 & 跑 & 婆 & & 批 & & & & 票 & & 晋 & & & & \\
\hline $\mid \mathrm{b} /$ & & 悲 & 擺 & 把 & 包 & 波 & & et & & & & 表 & & 部 & & & & \\
\hline $\mid \mathrm{m} /$ & & 每 & 買 & 馬 & 毛 & 磨 & & 米 & & & & 妙 & 謬 & & & & & \\
\hline |f/ & & 我 & & & & 否 & & & & & & & & 府 & & & & \\
\hline$M$ & & & 台 & 他 & 逃 & 拖 & 頭 & 題 & & & & 佟 & & \pm & 腿 & & & \\
\hline$|\mathrm{d}|$ & & 的 & 代 & 打 & 道 & 多 & $\underline{\underline{\theta}}$ & 祇 & & & 飱 & 掉 & 丢 & 肚 & 對 & & & \\
\hline III & & 你 & 來 & 拿 & 老 & 怒 & 肉 & 离隹 & & & & 遼 & 留 & 如 & 内 & & & 女 \\
\hline$|c|$ & 詞 & 支 & 才 & 叉 & 朝 & 初 & 酬 & 期 & & & 斜 & 橋 & 秋 & 除 & 吹 & 揣 & & 去 \\
\hline$|z|$ & 紙 & 遮 & 者 & 阽= & 早 & 左 & 州 & 雎 & 姐 & 界 & 家 & 交 & 久 & 諸 & 最 & & 㧓 & 據 \\
\hline$|s|$ & 思 & 舄 & 賽 & 侵 & 少 & 所 & 收 & 西 & & 懈 & $T$ & 11 & 休 & 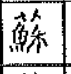 & 歲 & 狛 & 要 & 婿 \\
\hline$|k|$ & & & 䦕 & 卡 & 考 & 科 & 可 & & & & & & & 奖 & 雐亏 & \begin{tabular}{l|} 
筷 \\
决
\end{tabular} & 誇 & \\
\hline$|g|$ & & 给 & 街 & 加 & 来羔 & 過 & 棈 & & & & & & & 古 & 處帚 & 怪 & 掛 & \\
\hline $\mid \mathrm{h} /$ & & & 海 & 哈 & 好 & 河 & 侯 & & & & & & & 至 & 回 & 懷 & 化 & \\
\hline 11 & & & 也 & 啊 & 傲 & 我 & 嘼 & 夜 & 野 & 崖 & 牙 & 要 & 有 & 無 & 国 & 外 & 武 & 魯 \\
\hline
\end{tabular}


/en/ /an/ /an/ /on/ /ln//len//iren//ian//ion//uen//uren//uan//uon//yen//yæn/

\begin{tabular}{|c|c|c|c|c|c|c|c|c|c|c|c|c|c|c|}
\hline $\mathrm{p} /$ 盆 & 昐 & 旁 & 朋 & 平 & 馬扁 & & & & & & & 判 & & \\
\hline 本 & 辦 & 聟 & \begin{tabular}{|l|} 
崩 \\
\end{tabular} & 䆬 & 便 & & & & & & & 半 & & \\
\hline 門 & 慢 & 忙 & 猛 & 民 & 兔 & & & & & & & 渶 & & \\
\hline 分 & 之 & 方 & 豊 & & & & & & & & & & & \\
\hline 电 & \begin{tabular}{|l|} 
談 \\
\end{tabular} & 堂 & 通 & 㯖 & 天 & & & & & & & 團 & & \\
\hline 燈 & 撣 & 雷 & 冬 & 定 & 点 & & & & & & & 端 & & \\
\hline 人 & 懒 & 嚷 & 隆 & 令 & 念 & & 兩 & & & & & 熖 & & \\
\hline 塺 & 痖 & 豆 & 從 & 竌 & 錕 & & 墙 & 竅 & 春 & & 创 & 穿 & \begin{tabular}{|l|} 
辟 \\
\end{tabular} & 全 \\
\hline 珍 & 站 & 丈 & 中 & 今 & 具 & 間 & 江 & 窘 & 奖 & 賺 & 荘 & 專 & 君 & 卷 \\
\hline 身 & $\Xi$ & 傷 & 送 & 新 & 先 & 閒 & 鄉 & 晃 & 孫 & 测 & 隻 & \begin{tabular}{|l|} 
算 \\
\end{tabular} & 剖 & 喧 \\
\hline 肯 & 看 & 抗 & 空 & & & & & & 困 & \begin{tabular}{|l|} 
環 \\
\end{tabular} & 碌 & 䆓 & & \\
\hline 跟 & 感 & 㣚 & $I$ & & & & & & 棍 & 関 & 光 & 館 & & \\
\hline 很 & 㣮 & 杭 & 红 & & & & & & 嬏 & 還 & 竞 & 欢 & & \\
\hline 恩 & & \begin{tabular}{l|l} 
昂 \\
\end{tabular} & 翁 & 音 & 然 & 颜 & 揚 & 容 & 文 & 晚 & 綢 & 玩 & 建 & 元 \\
\hline
\end{tabular}




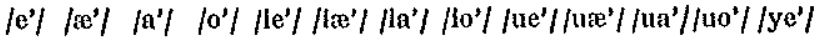
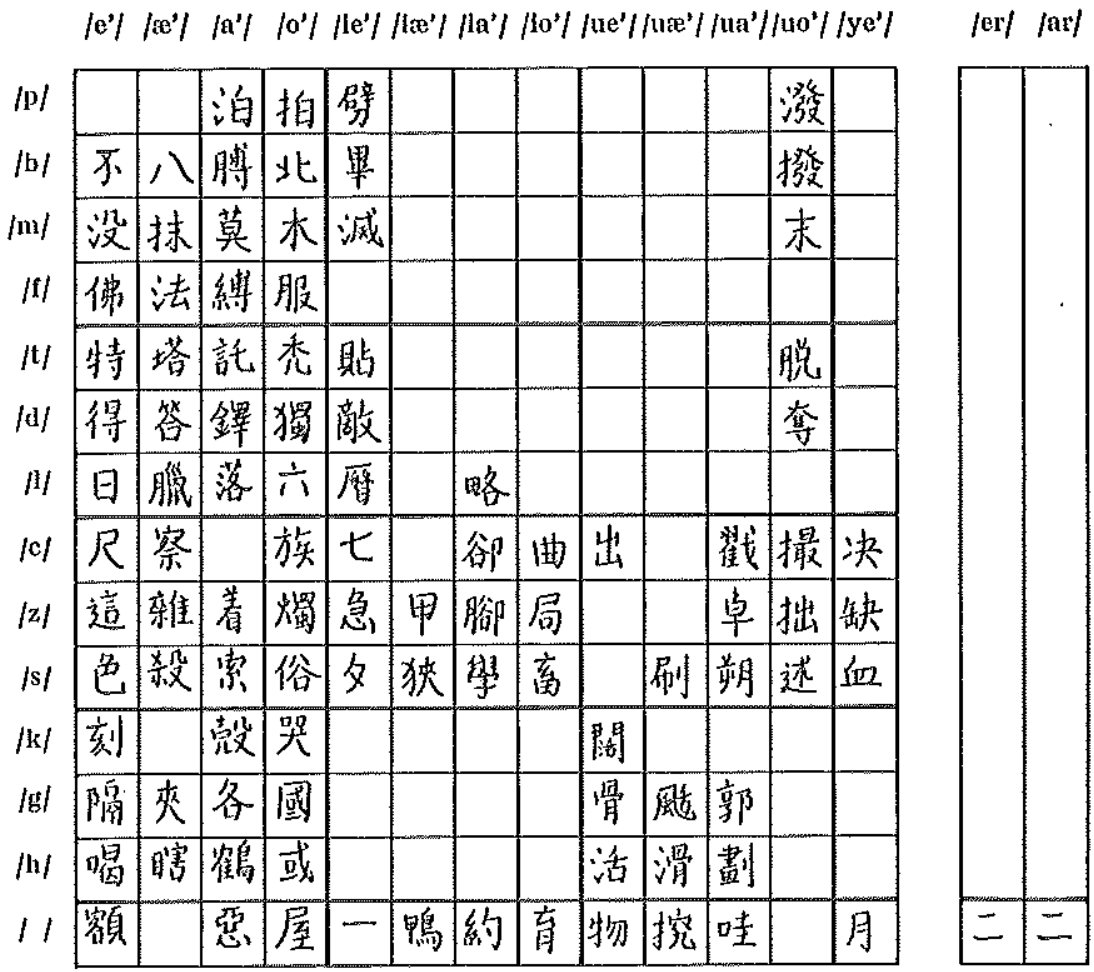


\section{Phonematic structure}

The syllable structure of the Yangzhou dialect can be sum. marized by this formula:

$$
\begin{aligned}
& \pm \mathrm{C} \pm \mathrm{V}_{1}+\mathrm{V}_{\mathrm{a}}\left\{\begin{array}{c}
+\mathrm{T} \pm / \mathrm{n} / \\
+|/|
\end{array}\right. \\
& \pm \quad \text { i.e. facultative } \\
& +\quad \text { i.e. obligatory } \\
& +\quad \text { i.e. either/or (one of the elements obligatory) } \\
& +\quad \text { i.e. all initials } \\
& \mathrm{V}_{1} \quad \text { i.e. } / \mathrm{i} /, / \mathrm{u} / \text { and } / \mathrm{y} / \\
& \mathrm{V}_{2} \text { i.e. } / \mathrm{i} /, / \mathrm{e} /, / \mathrm{e} /, / \mathrm{a} /, / \mathrm{a} /, / \mathrm{o} /, / \mathrm{u} /, / \mathrm{w} / \text { and } / \mathrm{y} / \\
& \mathrm{T} \quad \text { i.e. } / \mathrm{H} / \mathrm{N} / \mathrm{N} / \mathrm{H} /
\end{aligned}
$$

If $V_{2}$ is occupied by one of the vowel phonemes $/ \mathrm{i} /, / \mathrm{u} /$ or $/ \mathrm{y} /$, then no $V_{1}$ is possible.

Not all initials can combine with all finals. The following significant gaps are registered:

$/ \mathrm{p} /, / \mathrm{b} /, / \mathrm{m} /$ are not found before $/ \mathrm{o} /$ and $/ \mathrm{y} /$;

are only found before $/ \mathrm{u} /$ in the finals $/ \mathrm{u} /$, /uon/, $/ \mathrm{uo}^{\prime} /$ where $/ \mathrm{u} /$ is never manifested as very short [u]; are only found before /i/ in the finals /i/, /iå/, (/iw/), /in/, /ien and /ie'/.

/f/ is not found before $/ 0 /, / \mathrm{i} /$ and $/ \mathrm{y} /$;

is only found before $/ \mathrm{u} /$ in the final $/ \mathrm{u} /$.

$/ \mathrm{t} / \mathrm{d} / \mathrm{T}$ the same restrictions that apply for $/ \mathrm{p} /, / \mathrm{b} / \mathrm{,} / \mathrm{m} /$, except that $/ \mathrm{t} /$ and $/ \mathrm{d} /$ are found before the finals /ue/ and /ia/.

/1) is not found before /o/;

combines with $/ \mathrm{u} /$ and $/ \mathrm{i} /$ in the same finals as $/ \mathrm{t} /$ and $/ d /$, except the finals $/ \mathrm{uo}^{\prime} /$ and $/ \mathrm{ia} /$;

is however found before the finals /ian/ and /ia'/;

is only found before $/ y /$ in the final $/ y /$.

10 Aeta Orientalla, XXXvil 
$\mid \mathrm{k} / \mathrm{g} / \mathrm{g} / \mathrm{h} /$ are not found before $/ \sigma /$; before $/ \mathrm{i} /$ and $/ \mathrm{y} /$ we find the neutralization phonemes $|\mathrm{C} /,| \mathrm{Z} \mid$ and $\mid \mathrm{S} /$ (written in minuscule for transcription use).

$1 /$ is not found before $/ \% /$.

$|\mathrm{c} /,| \mathrm{z}|,| \mathrm{s} \mid$ have practically no limitation of occurrence before the finals. Before $/ \mathrm{i} /$ and $/ \mathrm{y} /$ we find the neutralized forms $/ \mathrm{C} /, \mid \mathrm{Z} /$ and $/ \mathrm{S} /$.

If this phonematic analysis is considered valid, it implies that we have to note a rather special phenomenon in the phonological structure of the Yangzhou dialect: no phoneme (including tone-phonemes and semi-tone-phonemes) can be repeated within the same syllable. This means that the sequence of phonemes does not have a phonematic function in this language, as it has in many other languages f.ex. French mal i.e. /mal/ $<>$ lame i.e. /lam/. ${ }^{22}$

The phoneme paradigms for each position in the syllable are filled in such different ways and the sounds in these positions manifested in such different ways that it was decided not to make any identification of the various sound categories in this analysis. The syllable in the Yangzhou dialect is found to have a very strict structure, and since the syllable encompasses at the same time the morpheme (exceptions to this are considered quite marginal), we arrive at the conclusion that the sequence of phonemes is non-distinctive within the smallest meaningful units, the syllable-morphemes. Given the phonemes $|\mathrm{i} /,| \mathfrak{| c}|,| \mathrm{z}|,| \mathrm{n} /$ and $/ \mathrm{H}$ there is only one possibility: the syllable /ziæn/.

\section{Comparison with the previous studies of the pronunciation of the Yangzhou dialect}

This study (V.B.) is compared to the studies by Wang Nianfang, 1959 (W.N.), Wang Shihua, 1959 (W.S.) and Hanyu fangyan cihui, 1964 (HYFYCH). All initials, finals and tones of the various descriptions are arranged in columns vis-à-vis each other in the tables pp. 291-93. My remarks on the different ways of description are found in the notes following the tables.

\footnotetext{
22 Cf. Martinet, 1967 p. 17.
} 


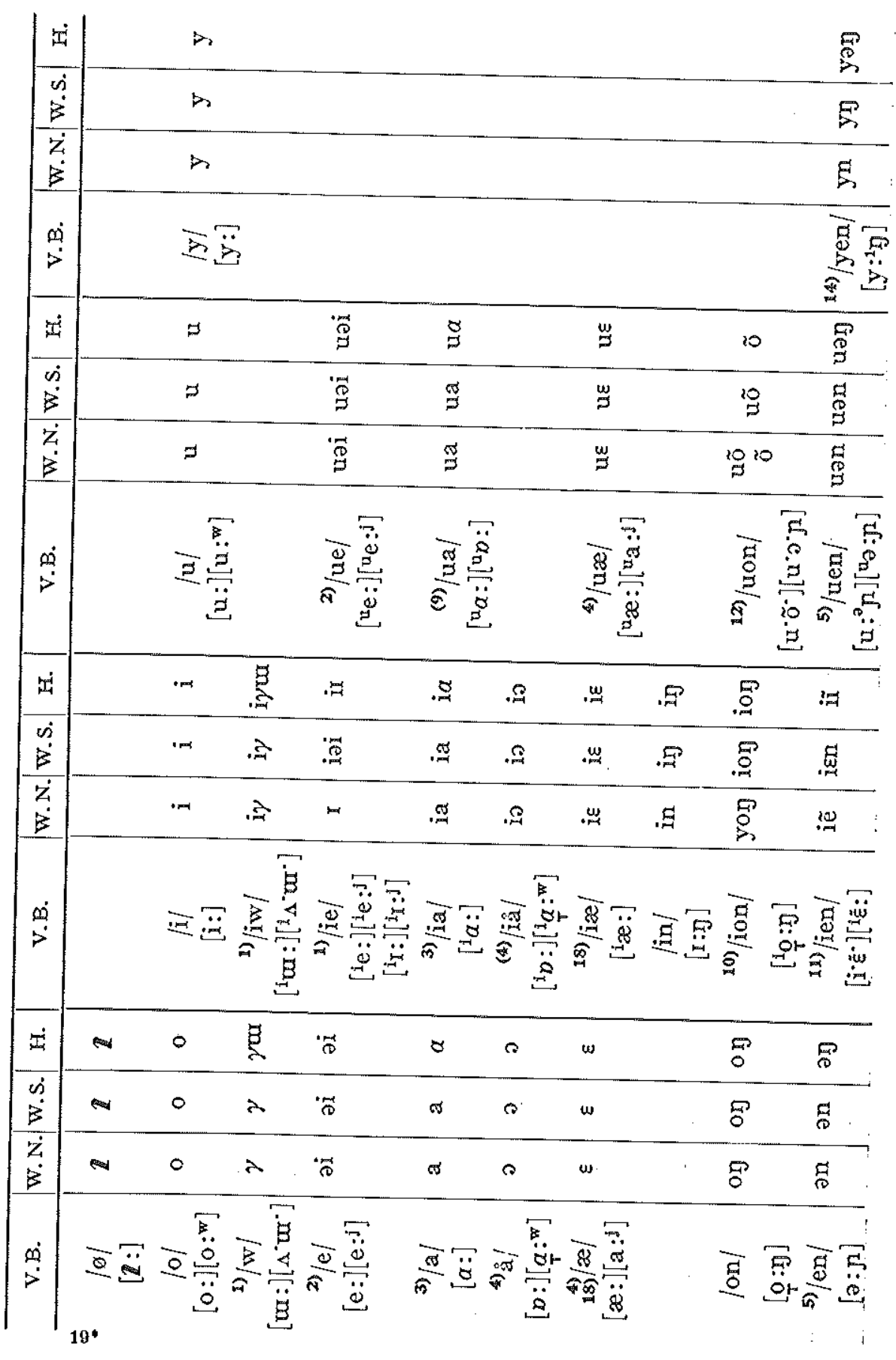




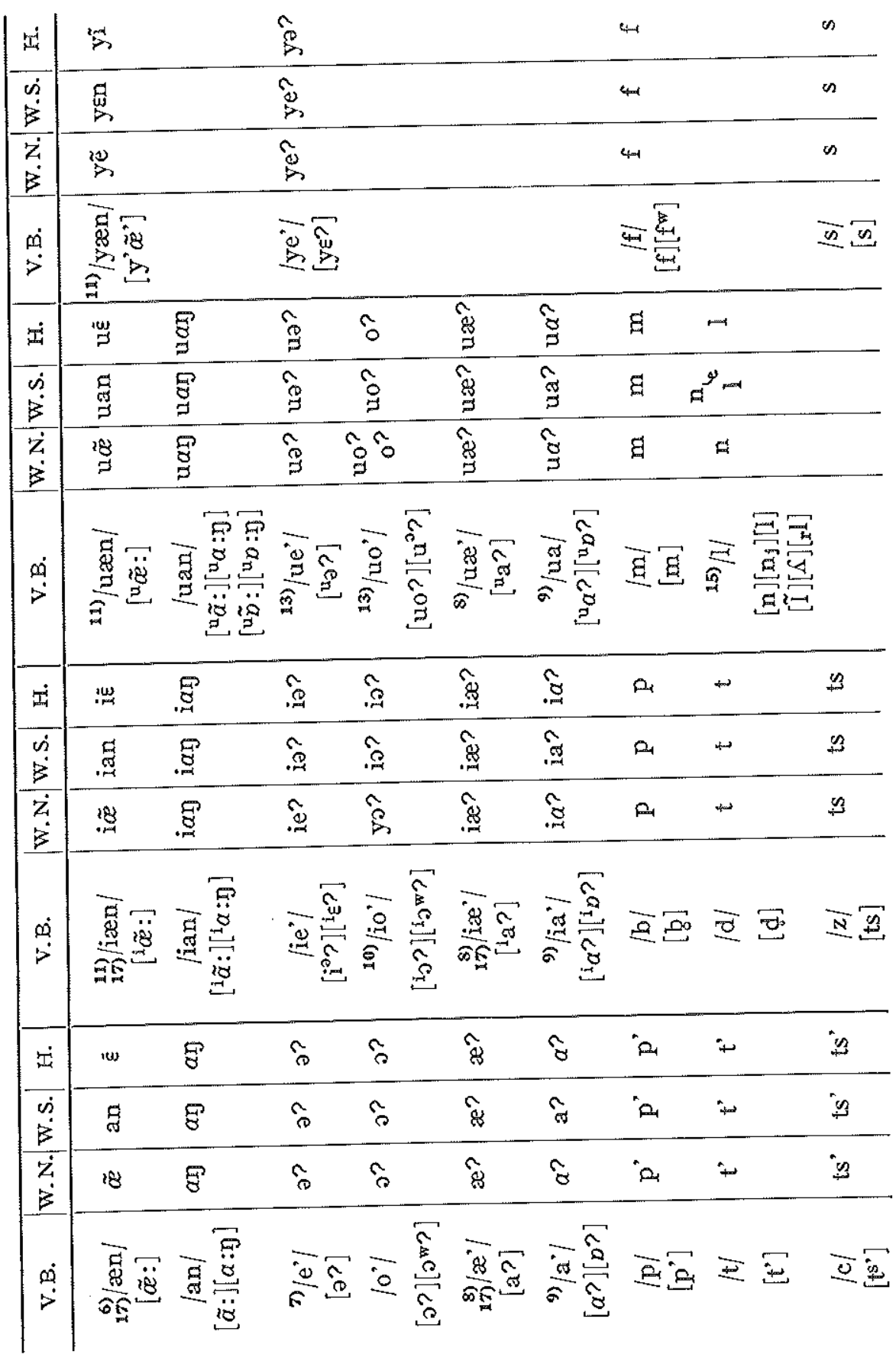




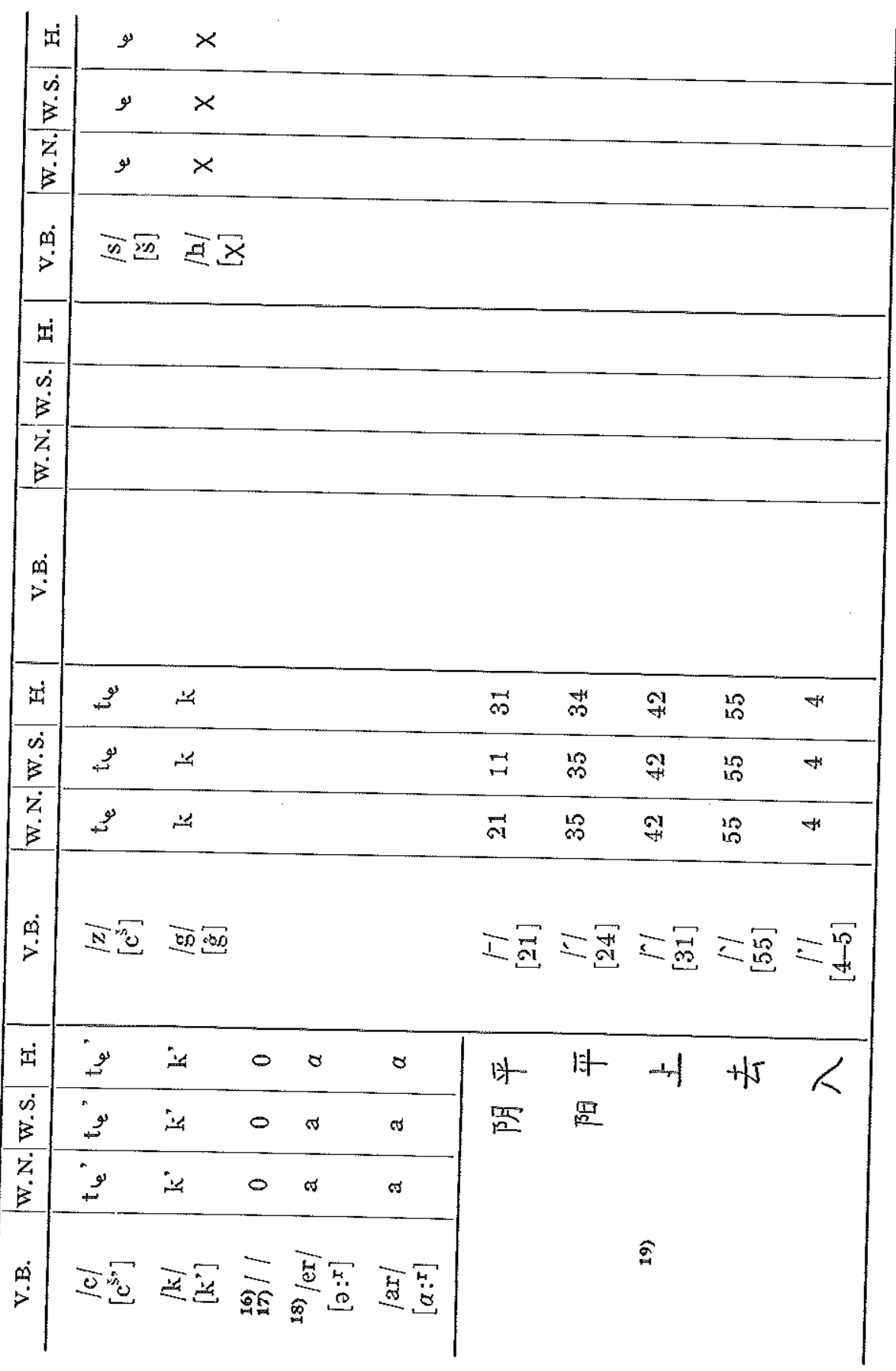


1) The free varlations given in V.B. explain the difference of transcription. There is some disparity concerning the vowel quality.

2) Cf. note (1). My informant seems to pronounce these finals with a more narrow central vowel than the somd observed by W.N., W.S. and HYFYCH.

3) There is some disparity concerning the degree of opening of the central vowel in these finals (perhaps due to different use of IPA),

4) Neither IV.N. nor W.S. nor HYFYCH deseribe these finals as diphthongs. The free variants $\left[a:^{w}\right]$ and $[a: J]$ of V.B. do perhaps show that the language of my informant is infuenced by putonghua forms. The other descrptions also give a somewhat narrower degree of opening for the central vowel, (4) diphthongs, read: triphtliongs.

5) There is disparity between IV.N., W.S. and HYFYCH concerning whether the nasal element is $[n]$ or $[y]$. I think the place of artfculation is nelther velar, nor alveolar, but palatal $[\mathrm{j}]$.

6) The degree of opening of the vowel and the mantfestation of nasality are again differently described.

7) In the pronunclation of my informant the glottal stop in the short finals was most often so faint that it was difficult to perceive whether it was there at all. It was latent and might always be heard if one asked for a slow and distinct repetition, but it seemed to me to have disappeared to a rather high degree at normal speech speed. This phenomenon was typleal for all the short finals. The other descriptions do not mention such a tendency.

8) There is some further discrepancy between W.N., W.S, and HYFYCH versus V.B. concerning the vowel qually. It seems to be owing to different use of IPA.

9) W.S, registers the vowel quality as [a] which is at difference with V.B., especially since free variation was found in my materlal between [ $\left.a^{\prime}\right]$ and $\left[b^{\prime}\right]$ (a still more open vowel). (9) Here both W.N. and W.S. register ua, whereas I have found the final manfested in the freely variating forms [ $\left.{ }^{\mathrm{u}} a:\right]$ and $\left[{ }^{\mathrm{u}} \mathrm{b}:\right]$.

10) W.N. considers this final an "y-final". It is actually difficult to decide on the pronunciation of my informant whether the glide is rounded or not. I have however kept my impressionistic notation as basis for the phonemte analysis. From a historical point of view the y-analysis might be preferred, since the rules of change will become simpler in that way.

11) There is a discrepancy concerning the vowel quality and the manifestation of nasality. All these "small differences" also mentioned above would actually lead to rather different phonemic solutions dependent on which phonetic notation was taken as point of departure. But the number of different syllables and the distribution of $\frac{1-3}{z}$, characters, to these syllables is very similar in all four descriptions.

12) W.N. spllts this flnal up into two (complementary) finals: ó after bllabial and lablodental initials, uof elsewhere. Of course the labial initials and the u-vowel Jave some common characteristics in the articulation, which means that an thsound may be absorbed into the labial or may not be clearly distinct from the preceding labial. In the pronunciation of my informant this phenomenon was very 
IItte felt and the final was registered as quite parallel to the uó flnal after the other Initials. HYFYCH describes the final as o throughout. Either the phonetic material of HYFYCH is different from that of V.B., W.N. and W.S., or HYFYCH perceives this fnal as a homogeneous sound, not a glide. HYFYCH then writes the distinetion $\sim$ contra $n$, so that the contrast to the final on is kept in that way.

13) In the description of W.N. the three fnals uo?, uo? and o? have complementary distribution; 12 ? after velar and zero initial, o? after labial initial and $10 ?$ elsewhere. In the description of V.B. and W.S. the two finals do not have conplementary relationship. Here we find a positive commutation between H $_{\text {V. }}$. $/$ cue\%, W.S. ts'ua? and 撮 V.B. /cuo', W.S. ts'uo?. HYFYCH does not supply enough vocabulary.

14) Descriptions V.B. and HYFYCH agree in considering the vowel not quite homogeneous, but there is some disparity in the quality of the second vowel. W.N. describes the nasality as a dental sound $n$, whereas the other descriptons write
the velar $n$.

15) In the deseription of W.S. we find a complementary distribution of the initlals $n_{\mathrm{e}_{e}}$ and $1: n_{\mathrm{e}}$ before $i$ and $y, 1$ elsewhere. Such a clear complementary relationship has not been found in the language of my informant, but a lendency to. wards n-coloured sounds before [ ${ }^{1-}$ ] (but not before [i:] and [ $[:]$ ) has been registered. W.N. and HYFYCH describe the sound as respectively 11 and l every-
where.

16) W.N. remarks that before $i$, $u$ and $y$ some semivocalic friction may be heard in place of zero initial (my [ $\left.{ }^{w_{-}}\right],\left[^{j}-\right]$ ).

17) After zero initial there is in my phonetic material a tendency towards free variation between morpheme-syllables / $\mathrm{e} /$ and $/ \mathrm{ke} / \mathrm{/} / \mathrm{en} /$ and /iren/. Further, the descriptlon of W.S. classifies morphene-syllables such as $\{\mathrm{E}$, 談 and 谟隹 (with the initials $t-, t^{\prime}-,{ }^{n}{ }_{e}{ }^{-}$) as belonging to the final ian. The descriptions of V.B., W.N. and HYFYCH classify them as belonging to the final $/ \mathrm{en} /, \widetilde{x}, \tilde{\varepsilon}$. Likewise the description of W.S. classifies morpheme-syllables such as 答, 塔, 䘡 as belonging to the fhal ia?. V.B. and W.N. classify them as belonging to the final $/ \mathrm{e}^{\mathrm{e}} /$, $\mathrm{e}$ ? (HYFYCF does not furnish enough vocabulary).

18) Neither of the three other descriptions registers an ending $[-x]$ in morphemes such as 二, 平, 巟 or 兒. These morphemes are in all of these descriptions transcribed as $a$ or a. The fact that my informant had free variation between $[a:],\left[a::^{r}\right],[0: T]$ in these words is probably due to putonghua influence.

19) W.S. describes the $\mathrm{P}$ 月 平 tone as a level tone, whereas V.B., W.N. and HYFYCH describe it as somewhat falling. There is also some discrepancy in the various ways in which the abruptness of the falling and rising of tones are perceived. 
|: 我是揚州人り。掦州在長江那個北岸。 掦州在長江的北岸。揚州是上很古的一 個城市:扡位在追個通河子。在運河的 這调家邊。揚州的這调地方的出座，扡 有魚米蓝的集散地。揚州是一倜右老的

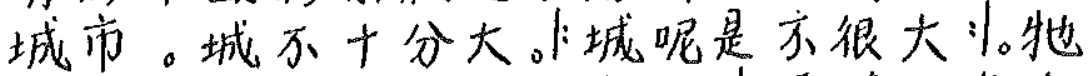
的週图呢，在四面只有，……面積只有十 公里归。交通方面呢，在這调交通方面呢 有上公共汽車川，水路有汽船，輪船，就 是……輪船，火輪船。揚州的這阅大多数 的人呢都是古老的，生活相當散漫的。 扡是由於遇去呢。我們家鄉是一個富裕

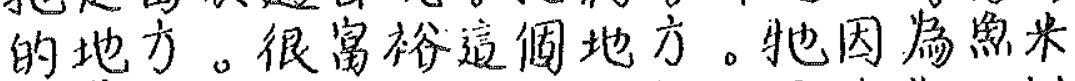
的集散地，牠的……所以1: 人民的收入就 比較好一点州。我一方面，人這個環境方 面呢，生活的息裕呢造成揚州人的一种 保守。或就可算是很獭情的。因学人民 生活富裕呢, 他的家座呢就富裕, 所以 他的子女呢就是受点教育，所以一点這

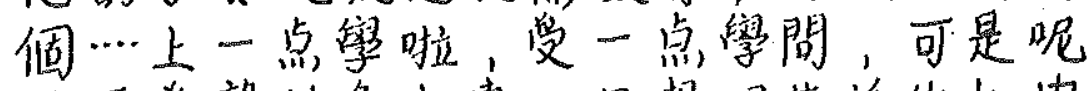
他不希望做多少事，只想呢生活的1: 安 裕的過下去米在掦州没有大的政治家， 没有大的電事家，只有呢做銀行的，做 諓莊的，做商人的。掦州所以很古老的 ，也很保守的，很落後的。所以我是掦 州人對揚州的想法。 
I.

ô sò ián-zW̄ilén / ián-zW̄ zè̀ cán-ziān là-gì bo'-iæèn / ián-zw̄ zè cán-ziăn-dè bo'-ièn / ián-zW sò hện gû-dè ie'gì cón-sò / tā ùe zè̀ ze'-gì' yèn-hó-zô / zàe yèn-hó-dè ze'-gì pán-biēn / ián-zW̄-dè ze'-gì dì-fān-dè cue'-cên / tă î̂̂ ý / mî / ién / dè zie'-sæèn-dì / ián-zW so ie'-gì gûn-1ân-dè cén-sơ / cén be' se'-fēn dà / cén lí sờ be' hên dà / tā-clè $z \vec{w}$-ué-lí, zà sơ-mièn ze' iŵ / mièn-zie' ze' î̂́ se' gōn-lî / zìa-tōn fān-mièn-lí, zìe ze'-gì̀ zìa-tōn fān-mièn-lí î̂w gōn-gòn cìcēe / sûe.utù î̂ cì̀cuón, lén-cuón, zî̀ sò / lén-cuón, hô-lén-cuón / ián-zָ̄-dè ze'-gì dà dö sù-dè lén-lí / dū sò gû-

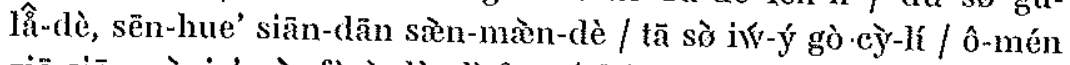
ziä-siān sò ie'-gì fư-ỳ-dè dì-fān / hên fù-ỳ ze'-gì dì-fãn / tă in-ué ý mî-dè zie'-sæè-dì̀, tã-dè / sô-î lén-mín-dè sw-le' ziẁ bîzìa hẩ ie'-diên / ô ie' făn-mièn, lén / ze'-gẀ kứen-zìn fān-mièn-lí, sēn-hue'-dè itw-ỳ-lí zå-cén ián-zW̄-lén-dè ie'-zôn bââ-sw / ho' zì̀ kŵ̂ suòn sò hên lân-dò-dè / in-ué lén-mín sën-hue' fù-ỳ-lí, tä-dè ziä-cên-lí, zì̀ fì-ỳ / sô-î tā-dè zồ-lŷy-lí, zì̀ sò sì̀ diên zỉa-io', sô-î̀.je'-diên ze'-gì / sàn ie'-diên sia'-lă, sì ie'-diĉn sia'-uèn /

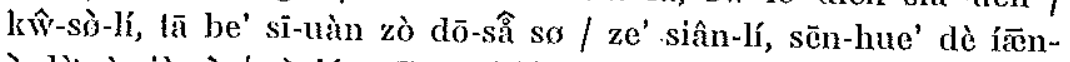

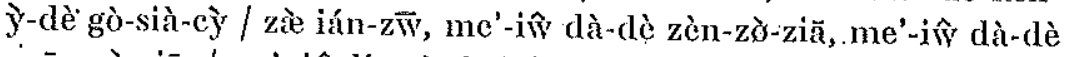
zyēen-sò-ziā / ze' î̂-lí, zò ín-hán-dè, zò cién-zuãn-dè; zò sãnlén-dè / ián-zW sô-î hên gû́-lầ-dè, ậ hên bẩ-sw-dlè, hên la'-hẁ-dè /

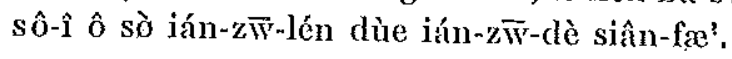

\section{I.}

/: I come from Yangzhou :/ /: Yangzhou is situated on the northern bank of Yangzijiang :/ Yangzhou is /: an old town :/ It is situated beside /: The Grand Canal :/ As to the production of the Yangzhou district there are fish, rice and salt markets. Yangzhou is an old town. The town is not large, all things considered. The town is not very large. It is not a very large town. In circumference it is on the four sides . . ./: The circumference only reaches $10 \mathrm{~km}: /$ As to the communications there are /: busses :/ and on the Canal there are steamers, paddle steamers. The vast majority of people in Yangzhou is old-fashioned. Life is rather desultory. This is due to the fact that our native district from of old is a rich district. It is rich, this district. Because of 
its fish and rice markets its ... then /: the income of the people is somewhat better :/ I for my part ... Now, the circumstances that people live in ... The wealthy habits have caused a rather conservative atlitude among the people in Yangzhou, or one might say that they are lazy. As people live a wealthy life and as their family properties are rich the children receive a little education, receive a little, go to school a little, have a little learning. But they don't want to work much. They only think that life must /: slip away pleasantly and steadily :/ In Yangzhou there are no great politicians and no great commanders. There are only bankers, brokers and businessmen. So Yangzhou is somewhat old-fashioned and conservative and backward. These are my thoughts about Yangzhou, the place where I come from. 
II.

掦州在長江的北岸。扡的位置在遇河的 旁邊。揚州是一個很古老的城市。也是 穌北的重鎮，長江献北的高素中樞。所 以有惫㸃集散地之称。

掦州城市万十分大。牠的週阅面積四十 公里。交通方面，陸路有公路，槥通薜 北各個影的地方。水路有連河, 為建輸 的主要線。

掦州是一個古老的城市。人民的生活方 式也是古老的, 保守的、善于豪受。道 是由於過去商業的繁盛，生活的富裕影 響造成了落後。

在揚州没有極大的政治家、科孟家、里 事家。他們希望他們的鬼女曼一点教育 安份守已過着古老的生活。万䝠多做 事䕀。只有做銀行、钱莊、和經商具多 数。所以掦州人的保守缺之了釗造精神。

II.

ián-zw̄ zæ cán-ziān-đè bo'-iæ̀n / tä-dè uè-zò zæ̀ yèn-hó-dè pán-

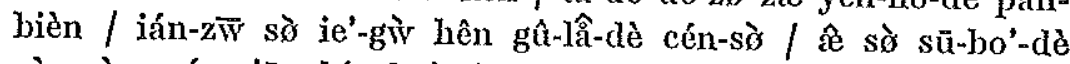
zòn-zèn, cán-ziān lán-bo'-dè sān-ie' zōn-sū / sô-î î̂ ý / ién /

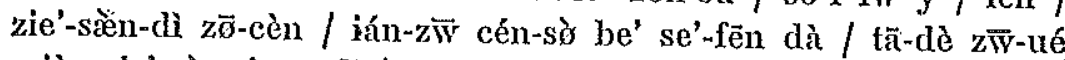
mièn-zie' sò-se' gōn-lî / zìătôn făn-mièn lo'-lù î̂ gōn-lù gî̀-tōn sū-bo' ga'-gẁ. sièn-clè dì-făn / sûe-lù î̂ yèn-hó ué yèn-sü-dè

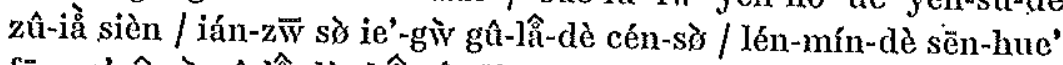

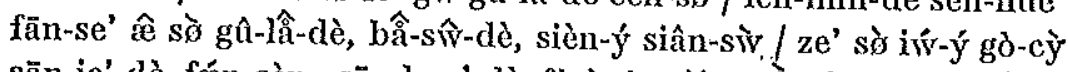
sān-ie'-dè fán-sèn, sën-hue'-dè fừ-ỳ în-siân zằ-cén-lîå la'-hì / zæ̀ ián-zW̄ me'-î̂ zie'-dà-dè zèn-zò-ziā, kō-sia'-ziā, zyën-sð̀-ziā / 


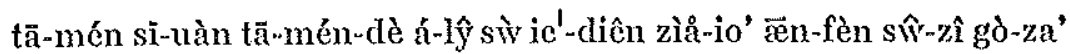
'gû́-lầ-dè sēn-hue' / be' yæ̀n dô zò sò-ie' / ze' î̂w zò ín-hán

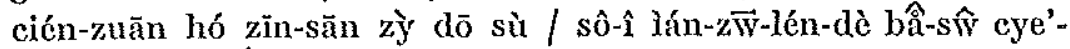
fæèn-liầ cuàn-zà̀ zin-sén /

II.

Yangzhou is situated on the northern bank of Yangzijiang. It is founded beside The Grand Canal. Yangzhou is a very old town. It is also the most important market in North Jiangsu and the center of the trade between the districts north and south of Yangzijiang. And that is indeed the reason why its fish and salt markets are so famous.

The town of Yangzhou is not very large. Its circumference reaches about $40 \mathrm{~km}$. As to communications there are roads connecting all the districts in North Jiangsu. As for the watcrways The Grand Canal eonstitutes the most important connecting line for the conveyance of goods.

Yangzhou is an old town. The habits of the inhabitants are also old-fashioned and conservative, easy to accept. The aftereffects of the earlier so rich trade and the luxurious life are that people have lagged behind.

No very great politicians, scientists, or commanders come from Yangzhou. They hope that their children can get a little education and live in the old traditional way satisfied with their destiny. They do not endeavour to perform feats. Only a lot of bankers, brokers, and businessmen can be found there. But the conservative attitude of the inhabitants has impeded the creative mind. 
III.

揚州好的地方。这就是好的地方。厂吃, 在我們家鄉吃很出名, 就是领食方面, 道個吃很出名。所以在我們家榔有一句 俗語: “上有天堂, ”就，“下有蔽杭”，吃呢 ，“吃在揚州，第在杭州”,也是，“住在䔻 州, 死在柳州”。揚州呢, 吃呢, 最於考 較很請究, 這就是由於過去生活的影響 。揚州吃要有色、香、味。不但考較咅 個吃得好吃，还要看得好看，这要很香 。揚州，所以……人呢，生活，所以道 種我㓮㴊講的呢，相當保守，所以扡的 一切呢由於通去的䍗境影留到人遥個影 鄉，到人民的一種彗落性。

揚州人呢还有一句話。這是一個厂賈加 馬加了呢。甚麼叫下買加禹加」呢? 掦 州人呢在清朝㴊刚初年的時候, 明朝末 年, 在景阎清朝起, 掦州有一個很大的 悲慘的事。L揚州十日言已7就是清朝進入 中国時候。入…入入主中國時候呢，就是 把揚州人呢通通殺光，所以揚州人有一 句俗語呢。广賈加馬吅, 呢, 這種呢, 就 是全城的人全都被殺光了。只有雨個姓 一一個姓馬的, 一倜姓賈的。随便揚州 人在景個交際方面有一種虚……追個虚偏 的説法呢，就是厂賈加馬如与呢，来呀， 坐呀, 談談呀, 玩玩呀, 你吃過飯呀, 坐坐呀，有空家玩玩呀。 
III.

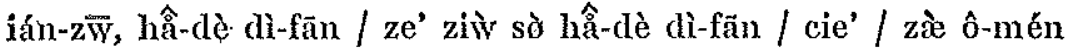
ziä-siān, cie', hên cue'-mín, zì̀ sồ în-se' fân-mièn, ze'-gì cie',

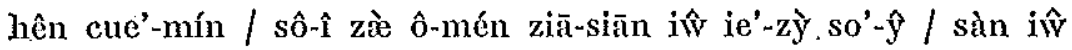

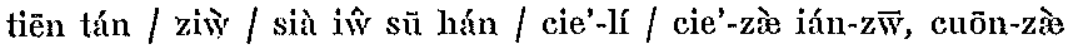

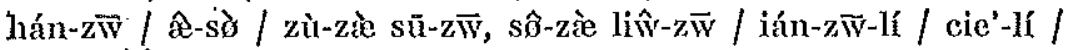
zùe ý kẩ-zìa hên ziân-ziẁ, ze' ziì sò iẃ-ý gò-cỳ sēn-hue'-dè in-siân / ián-zw cie' / ìå iw̄ se' / siân / uè / be'-dèn kầ-ziằ ze'-gì

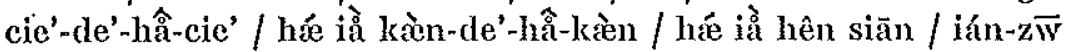
sô-î / lén-lí / sēn-hue', sô-î zẹ'-zôn ô gān-gān ziân-dè-lí / siān-dān bẩ-sŵ̀, sô-î tã-dè ic'-cic'-lí, iẃ-ý gò-cỳ-dè, kuén-zìn în-siân, dă

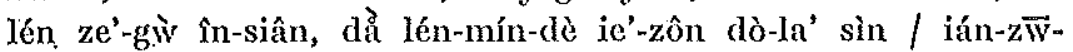
jén-lí, hre î̂. ie'-zỳ hùa / ze' sò ie'-gì ziâ-gä mâ-gä-lí / sèn-mö

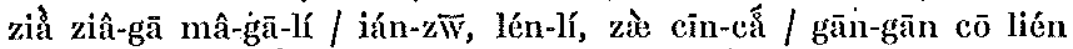
dè s6-hẁ, mín-cá muo'-lién, zà ze'-gì cin-că cî, ián-zW̄ iŵ ie'-gì

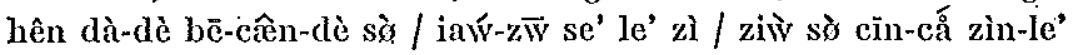

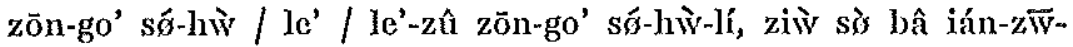

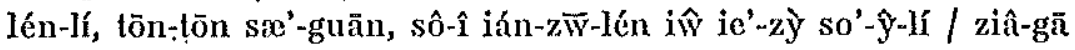
mâ-gä-lí, ze'-zôn-lí, zì̀ s̀̀ cyán cén-dè lén cyáen-dũ bè sæ'guān-lā / ze' î̂ liân-gì sin, ie'-gì sin mâ-dè, ic'-gì̀ sin ziâ-clè /

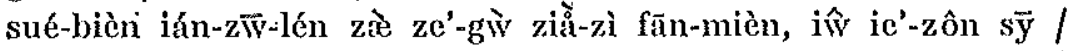

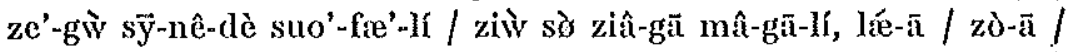

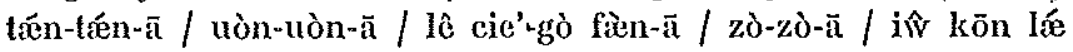
uòn-uòn-ā.

III.

Yangzhou is a wonderful place. It really is a wonderful place. As for example the food, in our native place the food is very famous. As to food and drink this food is very famous. Therefore there is a saying in our native place: "Up there we have heaven" and then, "down here we have Suzhou and Hangzhou" and the food, "you should eat in Yangzhou and be dressed in Hangzhou", and besides, "live in Suzhou and die in Liuzhou". Now the food in Yangzhou, what the beauty of it is, if you notice, is that it gives resonance of life from the old days. The food in Yangzhou must have both colour, odour, and taste. Please notice that it must not only taste good, it also has to look delicious and have a good 
odour. Yangzhou, the inhabitants, the life ... this almost conservative, that I have just told about, all of it is due to the aftereffects of the conditions in the old days, the effect it has had on people, the fact that people have become old-fashioned.

People in Yangzhou also say something else. It is "ziâ-gă mâ-gā". What does that mean, "ziâana mầ-gä"? In the very first years of the Qing dynasty, the last year of the Ming dynasty, i.e. when the Qing dynasty came into existence, a very sad event took place in Yangzhou. "The narrative of the ten days in Yangzhou", it is about the time when the Qing dynasty invaded China. When they invaded and became the masters of China they crushed the inhabitants. Therefore people in Yangzhou have a saying: "ziâ-gā mâ-gä". It is the sort . . . i.e. when the whole population of the town had been killed, only two families were left. One was called "mâ", the other was called "ziâ". When people in Yangzhou now visit each other for pleasure there is a mistake, this faulty use of the expression e.g. "ziâ-gã mâ-gā" come and sit down! Have you had anything to eat? Do sit down! Have you time enough to have a cozy chat? 
IV.

天下三分明月夜，二分明月在揚州。身 寻十䔽貫，騎鶴上掦州。

這是古人詩中形容掦州的好。掦州的好 ，俗語又説。广玡蒌州，住杭州，吃掦州 死柳州。戈所以揚州的吃很出名。吃不 但好吃, 而要考究香、味、色。由此可 見得掦州人的享受程度如何。在中國從

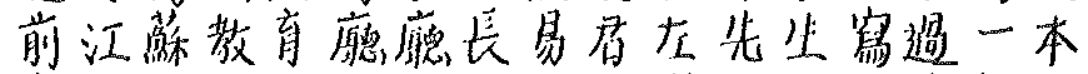
書叫閔誘揚州。批評掦州人早上皮包水 晚上水包皮。所䜊怎樣掯厂皮包水， 水包皮」呢? 就是早上掦州人起身時， 就先喝茶，而上午大部的時間又要在茶 館祬。商業的接頙或是交際上的應酬下 午义要在茶馏社生意的往来。或是閒空

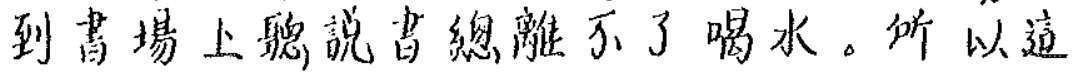
是皮包水。

所謂水包皮下午工作完棵後就進入澡堂 洗澡。把身子浸在温水中閉目食神。追

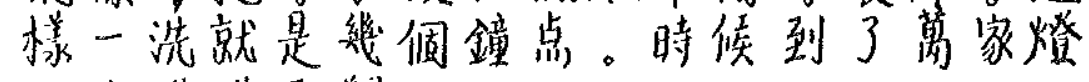
火才洋洋而蹱。 
IV.

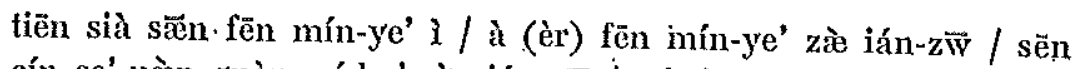
cín se' uæ̀n guòn, cí ha' sàn ián-zw / ze' sò gû lén sō-zōn sín-ión

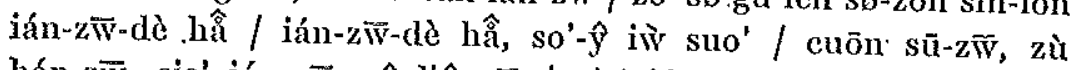

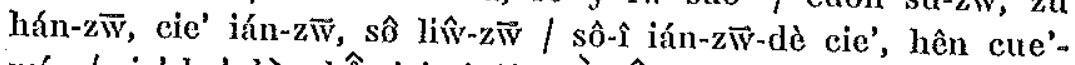
mín / cie' be'-dæ̀n hẩ-cie', á (ér) iằ kẩ̆-zî̀ / siān / uè / se' / î́ cô ' $\mathrm{k} \hat{w}$ zièn-de' ián-zw̄-lén-de siân-sì cén-dù lú-hó / zà zōn-go' cón-cién, ziān-sū ziằ-io'-tiñ tin̄-zân ì zyēn zô siēn-sēn sê-gò ie'bên sŭ ziă, sián-hùa ián-zẉ / pī-pín ián-zW̄-lén, zầ-sàn pí bā sûe, uân-sàn sûe bă pí / sô-uè zên-ián ziận pí bă sûe, sûe bă

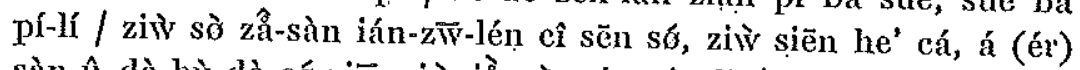

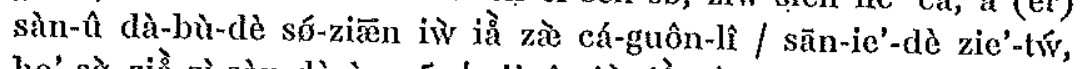
ho'-sờ zià̀-zì-sàn-dè ìn-cŵ́ / sià-tû, iẁ ià̀ zà cá-guôn-lî, sēn-ì-dè uân-láe / ho'-sð̀ siæen-kōn dằ sū-cán-sàn tîn suo' sū zôn lí-be'-lîå he' sûe / sô-î ze' sò pí bă sûe / sô-ù sûe bă pí, sià-û gổn-za'

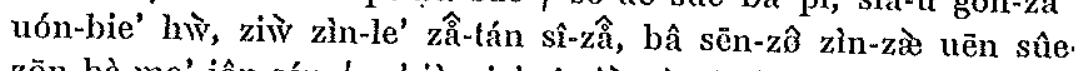
zoon bè-mo' iân-sén / ze'-iàn ie' sî zî̀ sò zî-gì zôn-diên / sǿ-hì dằ-liâà uæ̀n ziā dën hô, cá ián-ián á (ér) guē.

IV. "Two out of three of all moonlit nights in the world are in Yang-
zhou".

"One wants to find 10,000 crowns and flies to Yangzhou sitting astricle a crow".

This is the way in which the old so poetically have described how wonderful Yangzhou is. There is also a saying about that, "To be dressed in Suchou, to live in Hangzhou, to eat in Yangzhou, to die in Liuzhoul". The food in Yangzhou really is very famous. The food does not only taste good, but you can notice both the odour, the taste, and the look. From these things you can see how easy life is for people in Yangzhou. Mr. Yi Junzuo, a commissary in the education committee of the provincional department in Jiangsu in China, once wrote a book with the tille, "Small talk about Yangzhou". He critizises that in the morning people in Yangzhou "have the skin around the water" and that in the evening they "have the water around the skin". How to explain the expression that the skin is around the water and that 20 Acta Orientalia, XXXVIII 
the water is around the skin? It means that when people in Yangzhou get up in the morning they start drinking tea, and in the forenoon they also spend the greater part of the time sitting in the tea house. Also in the afternoon there usually are comings and goings of businessmen making agreements and people that amuse themselves in good company. And when people in their spare time go to the village hall to attend some reading aloud they drink tea without pause. That is what it means that the skin is around the water. 'The expression: the water around the skin: in the afternoon when work is over people go to the swimming baths to take a bath and they plunge into the warm water, close their eyes and relax. And when they have been bathing for a little while several hours have passed. Only when there is light in all the houses people return home, refreshed. 
V.

\section{俊女婿科喜( 笑話)}

有一天侵女婿的老婆同他講啦。

明天我的父親就要帛生日时立。我們要 去拜青呀。惨你這樣俊頭像腦的出去息 了人太不像椂啦。你呢一定要想個辦法 學一㽡。”

俊女溃説。”要我學甚麼呀。”

老婆就賟啦。“你呀无閒看到人在言談上 方都要雪一点言詞、態度、文雅点，才 衣會失䄚呀。”

俊女婿包答老婆説。“這调還不是客易的 事。我會, 我會做。”

他的老婆説。”不、不，不。你一定要到 外面去學一壆。”

俊灰婿説。”好，好，好。”

於是他穿了夜服, 拿了媛, 就出了門。 㓮㓮出了阿不久, 他的肚子痛起来了。 啊呀, 要大便了。”他急急忙忙跑進了

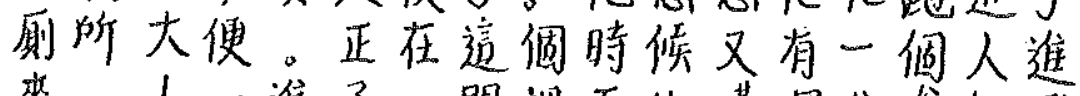
来。人一進了, 門裡面的蛤䖶嗡嗡起我

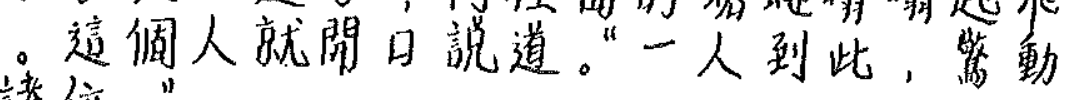
諸位。

俊子一聽，“這句話倒不錯，我要記住把 㑩子大便後出了毛前阴来到河邊口。看

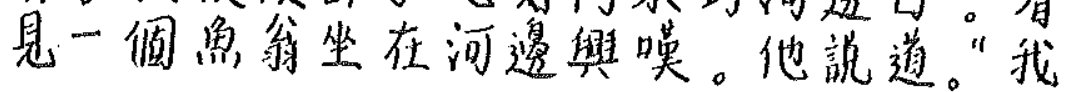




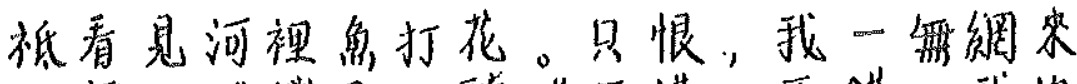
又無义。”俊子一奍。“不錯, 不錯。我也 要記住遥句話。祗看县河裡魯打花。只 恨, 我一舞终又無义。

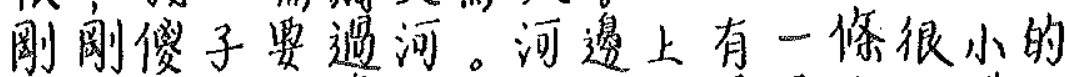

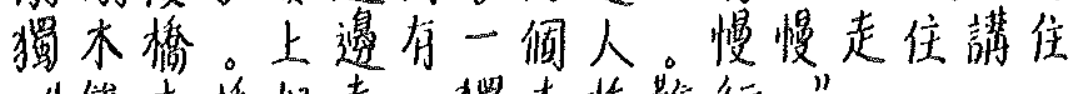

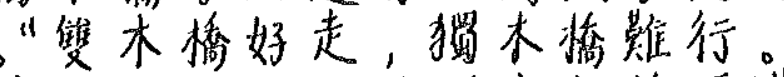

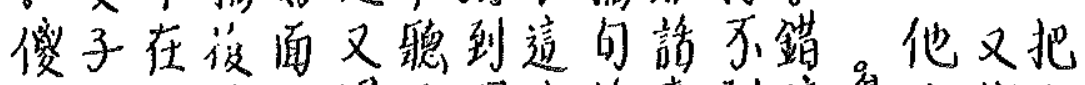

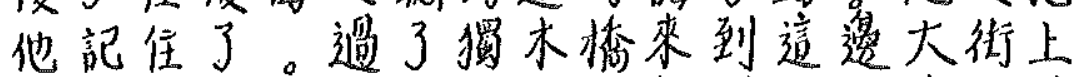
街上人來来往往好可槊闌。在這调時

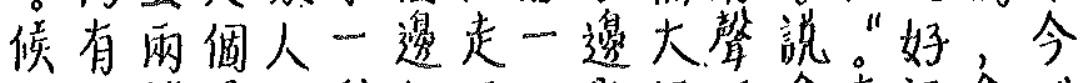
天不談了。我們明天影祼不會府福會。” 修子一疆，又記住了这句話。

像女婿記住這我句話，得意洋洋回来㙚

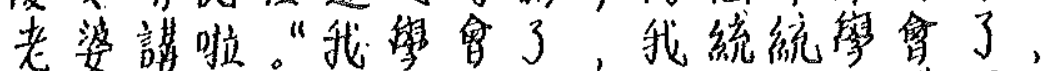
明天我㑚去拜喜。包險你, 我會説得漂 亮，不用你煩心了。”

老婆説。“好，既然你會隻到許多啦，明 天我同你去拜青吧。

景天像子的岳父過六十大芸。親或朋友

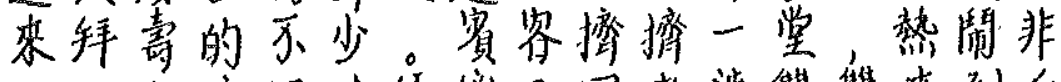

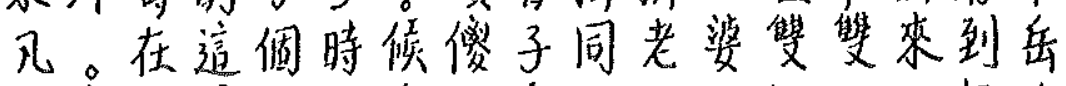
父家的阴口。手中拿了大一包小一包的 禮物，走進来。全堂的人一看，大家不 约同聲説道。“俊子回来了，俊女婿回来 了。”夫家都有一种像看方起僈女㧹的表 
示。丈人与丈贯雙雙忙迎接女免女婿颔 。心中在打掛希望他的女婿不要有像 頭僈腦這种俊氮。

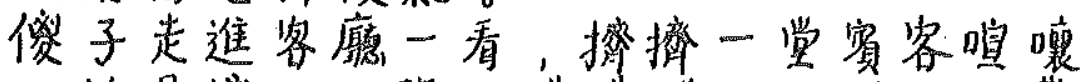

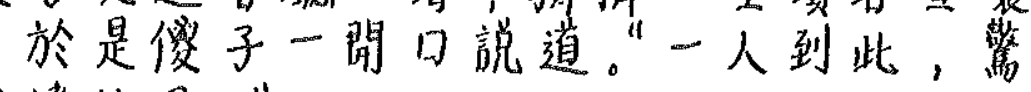
動諸位了。”

全堂的人一㯖。“㘈，俊女婿不錯，言詞 非常有禮。”大家都在懷疑着。可久酒就 擺下, 準借開席。大家都説。”請坐, 噇 坐。”俊子同時也坐下来了。這時候有兩 㧽客人小聲説道。“俊子现在不像，現在 倒要試他一試。”於是全桌山珍海味。各 人的面前都有碗筷。惟㯰俊子面前没有 大家都説。”請用, 腤用。”大家都拿着

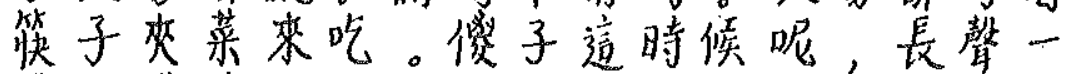
嗼的説道。“我祇看見河社魯打花。我恨 是一橆網菜又無义。”

旁邊的人一聽—警。”怪呢, 俊女婿不壊 啦，不好，我假京能欺騙他了，快点把 碗筷拿給他吧。”

旁邊又有一個人出了主意。“我們给他一 隻筷子俭他舟来試他一下。”於是給了一 隻筷子。俊子普没有去拿一隻筷子就説 。”單木橋難行，隻木桥好走。”

大家一疆。”不好，不好，不能再欺騙他 了。快点把碗筷送到俊子面前。” 


\section{酒席吃完, 大家预借散席起身啦, 俊子 呢站起身来, 大整境。”好, 今天我們不 談, 明天影裡不自, 府祬會。”}

V.

$s a ̄-l \hat{y}-s \bar{y}$ bè-swiv / siằ-huà /

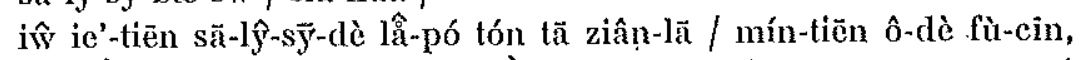

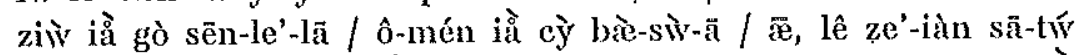
să-lầ-dè cue'-cỳ zièn-liẩ lén, tæ̀ be' siàn-iàn-lā / lê-lí, ie'-dìn iằ siân gìr-bæ̀n-fá' sia'-ie'-sia'।

sā lŷy-sȳ suo'/ iằ ô sia' sén-mô-ă /

lấ-pó ziẁ ziân-lă / lê-iã, be' uèn, kæen-dă lén, zà ién-trén-sàn / dũ iằ sia' ie'-diên ién-có, tì-dù, uén-iâ-diên, cáe bc' huè se'-lî iã /. sā-lŷy-sy̆ hué-dæe lậ-pó suo' / ze'-gì huàn be' sò ión-ì-dè sò / ô 'huè, ô huè zò / tâ-dè lầ-pó suo' / be' be' be' / lê ie'-dìn iằ dầ uàe-mièn cỳ sia'-ie'-sia'/

sā-lŷy-sÿ suo' / hầ, hầ, hẩ /

ý-sò tã cuōn-liầ i-fo', lá-liâa ciẹn / ziẁ cue'-liâă mén / gān-găn cue'-liââ mén be' zî̂, tã-dè tù-pí tòn-cî-lée-lā /,

ã-iā / ià dà-bièn-lā / tā zie'-zie' mán-mán pắzin-liâa số-sô dàbièn / zèn zæ̀ ze'-gì sǿ-hwे, iẁ î̂ ie'-gẁ lén zìn-láe / lén ie' zìn-

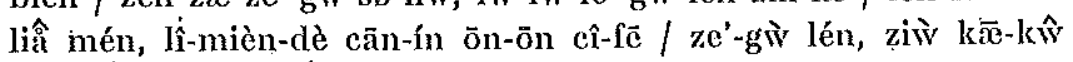
suo'-dầ / ie' lén ·dằ co / zin-dòn zū-uè /

sã-zố ie' tin / ze'-zỳ huà dà be' cò, ô ià zì-zù tā /

să-zố dà-bièn hẁ, cue' liầ má -sô-mén lá-dằ hó-biën-kŵ / kæènzièn ie'-gì ý-ōn zò-zàe hó-biēn sinn tæen / tă suo'-dằ / ô dỉ kæ̀n-zièn hó-lî ý dâ-hụă / ze' hèn, ô ic' ú uân laé, î̀ ú cā / sā-zồ ie' lĩn / be'

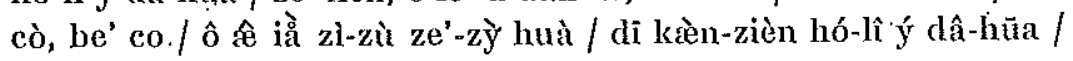
ze' hèn, ô ie' ú uân láe, ì̀ ú cã /

gãn-gān să-zố ià̀ gò hó / hó-biēn-sàn iŵ ie'-tiă hên siầ-dè do'mo'-ciá / sàn-biēn î̂ ie'-gẁ lén / mæ̀n-mæ̀n zŵ̀-zù ziân-zù /

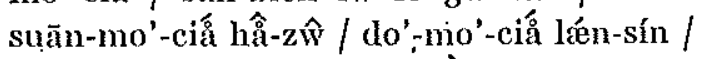

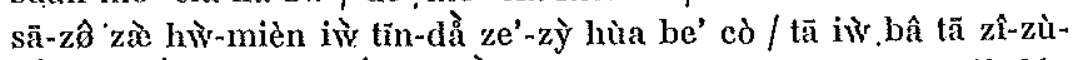

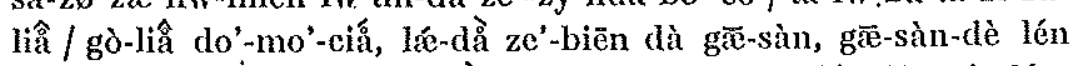
láe-lǽ uân-uân hâo be' ie'-lằ / zæ ze'-gî sớ-hì, î̂ liân-gì lén, 
ie'-biēn zî́ ie"-biën da-sẽn suo' / hẫ, zin-tiën be' tǽn-liầ / ô-mén mán-tiēn sièn-lî̀ bc' huè, fû-lî huè /

sã-zố ie' tīn, î̀' zì-zù-lià ze'-zỳ huà / sā-lŷ́-sy̆ zì-zù ze'-zî-zỳ huà, de'-ì ián-ián hué-lá cluè lầ-pó ziân-lă / ô sia'-huè-lā, ô tôn-tôn sia'-huè-lă / mín-tiën ô-mén cỳ' bæè-sw / bä̉-siên lê, ô huè suo'de'-pià̀-liàn / be' iòn lề fán-sinn-liâa /

lẩ-pó suo'/ hầ, zì-ién lê huè sia' dầ $s \hat{y}$ đlö-lä / mín-tiēn ô tón lê cyે bæ̀-sì̀ bà /

ze'-tiēn sä-zố-dè ia'-fù gò lo'-se' dà-sìv /

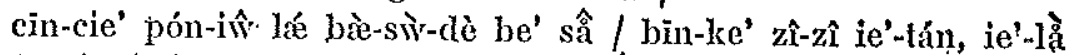
fê-frén / zà ze'-gì sớ-hẁ sā-zô, tón lậ̂-pó suān-suān lá-dầ ia'-fừ

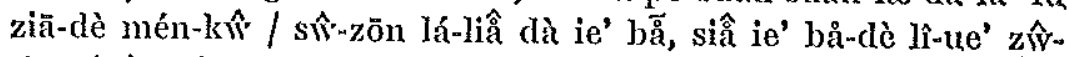
zìn-lá / cyán tán-dè lén ie' k kèn dà-ziã be' ia' tón-sën suo'-dà̀ /

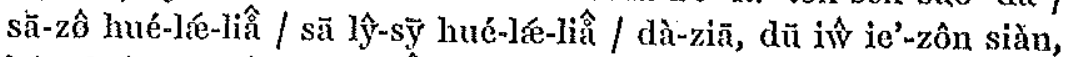
kè̀n-be'-cî sā-lŷy-sy-dè biầ-sø̀ / zàn-lén $\hat{y}$ zàn-mô, suān-suān mán ín-zie' lŷy-á (ér) lŷ-sȳ-lä / sīn-zōn, 仓̂ zæ dâ-guà, sī-uàn tā-dè

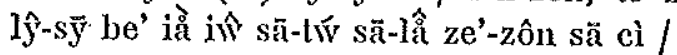

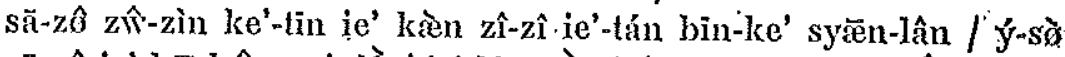

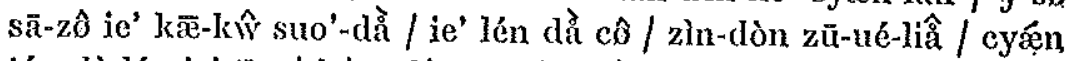
tán-clè lén ie',tīn / í / sä lŷy-sŷ be' cò / ién-có fẻ-cán î̂-lî / dà-ziä

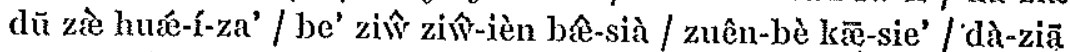
dủ suo' / cîn zò / cîn zò / să-zố tón-sớ 免 zò-sià-láe-liầ / ze' sǿ-hì jî̀ liân-gì ke'-lén siẩ-sēn suo'-dà̀ / sã-zô sièn-zà be'sä /.sièn-zæo

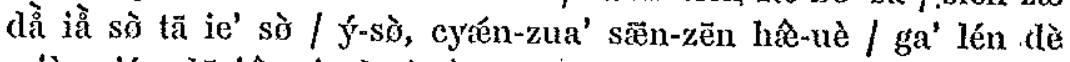
mièn-cién dả î̂ uôn-kuà / ué-do' sā-zộ mièn-cién me'-î̂w / dà ziā dū suo' / cîn iòn / cîn iòn / dà-ziā dü lá-za' kuæ̀-zố gæà cà láe cie' / sã-zố ze' só-hì-lí / cán-sēn ie' tàn-dè suo'-dả / ô dỉ kæ̀̀n-zièn hó-lî ý dâ-lhuă / ô hèn sờ, ie' ú uân lá iẁ ú cã / pán-biën-dè lén ie' tīn, ie' zìn, guæ̀̀-lí / sä lŷ-sy̆ be' huè-lä / be' hầ, ô-mén be' lén cï-pièn tă-liầ / kuà-diên bâ uôn-kuæ lá ziè tā bà / pán-biēn iẁ iŵ ie'-gì lén cue'-liâk zồ-ì / ô-mén, zie' tă

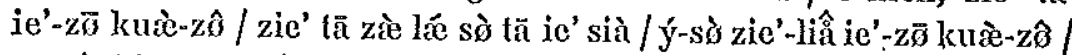

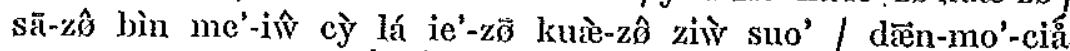
lán-sín / suän-mo'-ciá hâa-zî́ /

dà-ziä ie' tin / be' hầ / be' hầ / be' lén zæè cị-pièn tâ-liâa / kuà-

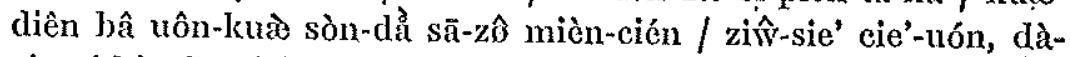

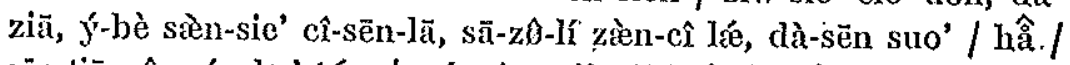
zīn-tiẹnn ố-mén be' tán / mín-tiēn sièn-lî be' zièn / fû-lî huè. 
V.

The stupid son-in-law on a birthday visit.

A witty story.

One day the stupid son-in-law's wife said to him, "Tomorrow is my father's birthday. We will have to pay a birthday visit. But, it is too unbecoming to visit other people when one is so oafish as you are. We surely have to find out how to get you a little learning."

The stupid son-in-law said, "What do you want me to learn?"

His wife said, "Don't ask me, but look at people when they talk, notice some expressions and good manners, and try to become a little cultured in order not to break the rules of etiquelte."

The stupid son-in-law answered his wife, "Isn't that rather easy? I am sure that I can manage that!"

His wife said, "No, no, no, you must go out and learn it." The stupid son-in-law said, "Well, well, well."

Then he put on his coat, took some money and went out of the door. No sooner had he come outside the door than he had a stomach ache. "Well, I'll have to relieve nature!" He hurried to a bog to do that. Just at this point another man came in. Just as he entered all the flies inside the door flew buzzing up. Then this man exclaimed, "All alone $I$ enter and the whole party is stirred."

When the stupid man heard that (he thought), "This sentence was not bad at all. I must remember that."

When the stupid man had relieved nature and left the bog, he came to a riverside. He saw a fisherman who sat sighing at the riverside. He said, "I see the fish in the river move their fins. How hateful, that $I$ haven't got a single one in my net or on my lister."

When the stupid man heard that (he thought), "Not bad at all, not bad at all. I must remember that sentence too. I see the fish in the river move their fins. How hateful, that I haven't got a single one in my net or on my lister." Now the stupid man was about to cross the river. Across the river there was a very narrow bridge plank. And a man was crossing it slowly, saying, "It is 
easy to cross a bridge with two planks, but difficult to cross a bridge with one plank."

The stupid man, that went behind him, also heard this sentence that was not bad at all; and he remembered it. When he had crossed the bridge he arrived at a large road on this side. On the road people were coming and going in a lively bustle. Then two men said loudly while walking, "Well, we won't talk more today, tomorrow we shall probably meet again, if not in the district, then in the prefecture". When the stupid man had heard that, he also remembered that sentence.

As now the stupid son-in-low carried all these sentences in his head, he returned proudly and happily to his wife and said, "I have learnt it now. I have learnt it completely. 'Tomorrow we'll pay the birthday visit. Don't worry. I can talk fashionably, so you need not be annoyed." His wife said, "Well, as you have learnt that much, let us pay the birthday visit together tomorrow."

That day the stupid man's father-in-law completed his sixtieth year and quite a few relatives and friends had come to pay a birthday visit. The guests were closely packed together in the room and everybody was having a very good time. At that point the stupid man and his wife arrived at the entrance to the house of the father-in-law. Bringing a big parcel and a small parcel as gifts they entered. No sooner had the people in the room scen them than they all of them exclaimed unanimously, "The stupid man has returned!" Everybody looked as if they thought nothing of the stupid son-in-law. The father-in-law and the mother-in-law hurried to welcome their daughter and son-in-law. They thought to themselves that they wished that their son-in-law wouldn't behave too oafishly.

As soon as the stupid man entered the sitting-room and saw the whole room packed with guests all in a hubbub, he exclaimed, "All alone I cnter and the whole party is stirred!"

When all the people in the room heard that (they thought), "Oh, the stupid son-in-law is not bad at all. That was unusually" politely said." And everyone was astonished. Shortly after the feast began and people prepared themselves to go to dinner. Everybody said, "please sit down!" The stupid man also sat down. 
Then two of the guests whispered, "the stupid man doesn't seem so stupid any morel But first we must try him a bit!"

Now a lol of selected specialities and delicious dishes were brought in. In front of each guest there was a bowl and a pair of chopsticks. Only in front of the stupid man was neither. Everybody said, "Please have something!" Then each of them took the chopsticks and began to eat. Then the stupid fetched a deep sigh and said, "I see the fish in the river move their fins. How hateful, that I haven't got a single one in my net or on my lister!"

As soon as people beside him heard that, they were very astonished, "That was peculiarl the stupid son-in-law is not so stupid after all. That was worse. Now we cannot cheat him anymore. We had better hasten to fetch a bowl and a pair of chopsticks for himl" Then a man beside him made a proposal, "Let us give him one chopstick to test him once morel"

'T'hen they gave the stupid man one chopstick. However', the stupid did not take this single chopstick, but said, "A bridge that consists of one plank is difficult to cross. A bridge that consists of two planks is easy to cross!"

As soon as all the others heard that (they said), "That was worse! Now we cannot cheat him anymore. Let us get hold of a bowl and chopsticks for the stupid man."

When the feast was over and everybody was getting ready to rise from table, the stupid rose and said in a strong voice, "Well, we won't talk more today. Tomorrow we shall meet again, if not in the district, then in the prefecture." 
VI.

現在談談過年。西方過的新年，中國人

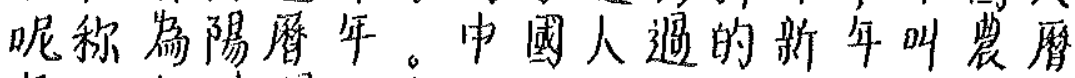
年。在時間上有先後之分。但中國人遇 農糜年比陽磨年隆重。年追㮯名詞呢㹉 傅説，葱年以前的洪垶時期就是初民時 代，年是一種動物，看束似牛非坐的冷 血動物，名子叫年贆。牠的性情極端的 偊洜。每隔三百六十天就要出来四處吃 人。遇者不免。年鱾出動的時候是在冬 春交際的時候。但是呢扡最怕紅色，火 光，大的馨普，所以人㑚每隔三百六十 天，就要躲避年默的災踓。所以家家都 把阴緊閉了，在阴上或鸦上都斯起紅纸 頭，全家都圈聚在一起升起火盆，大放 炮竹来抵缶年獸，就是使年㩆县到红色 、火光与大的㢣音，便會立刻警走而人 們呢藉此跑過了遥㧽難関。第二天一早 大家息了面, 都互相虔贺。大家都末被

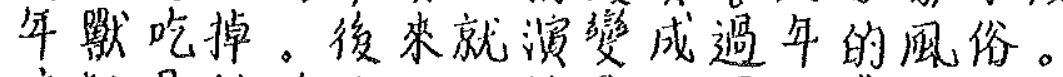
這都是神話的。比較是合理的説法。申 國是以震治國。秋收之後就是寒冬, 是 不能耕种。在遥涸時偾呢, 是空閒的, 要到春天才能開始耕作。所以呢, 這時 候又是曹收, 又是空閒。所以来蝔祝一 下相互的恭賀。 年獸似牛非牛, 所以古人造字, 年与牛 
字有点相似，年来代表三百六十天的一 倜時間的名子。

農曆遇年, 習慣是很多。在中國呢大致 相同。现在説到揚州人的過年。其先説

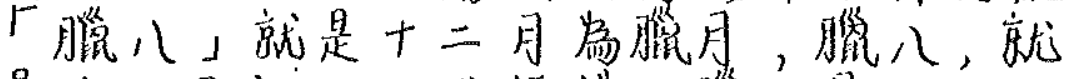
是 $十$ 二月初八。俗語説: 慆八邀, 就把 年货辫。甚麼叫年貨呢。就是盐㽣菜, 㸃雉、盐魯, 盍肉, 磨米粉, 做点心、 蒸年糕。撣鷹做新夜来迎接新年㕸。 厂送灶。送灶有雨天。二十三,二十四。 據傅説，是里三民四，在国家做事的人 呢是二十三送灶, 上十10呢, 是平民送 灶。

晚上送灶的時候呢，在到灶台上点起香 㯰，非常的㳟敬説: 灶神是一家之主， 上天言好事, 下界保平安。

除夕, 除久呢, 就是三十晚上。三十 晚上呢，也是相常隆重。

每家道天晚上要辤年謝神。這是甚麼意 思, 就是一年過去了，要感謝神的保作 ，所以晚上呢大家要吃年夜飯，年夜飯

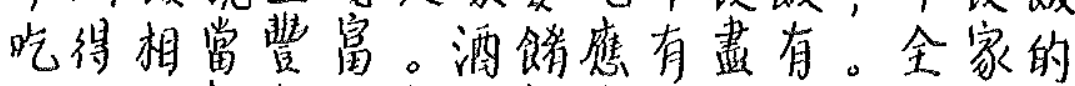
人呢, 都在坐在一起来吃。假如有一個 家裡的人不在此地或是在外面，不能来 吃飯的話, 桌子上也留出一個位置或一 倜碗筷一碗领啦, 就是懷念, 他的家人 在外面。 
VI.

sièn-zæè tán-tren gò-lién / sī-fän gò-dè sīn-lién, zōn-go'-lén-lí, cēn-tıé ián-lie'-lién / zōn-go'-lén gò-dè sinn-lién ziằ lón-lie'-lién /

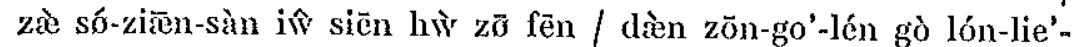
lién bî ián-lie'-lién lón-zòn / lién, ze'-gì mín-cớlí, zỳ cuón suo',

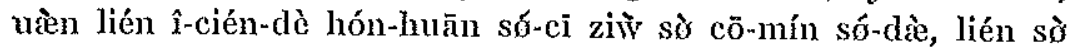
ie'-zôn dòn-ue' / kàen-láe sờ liw fể li̛r-dè lên-sye' dòn-ue', mín-zô ziằ lién-sì / tā-dè sìn-cín zie'-duōn-dè siön-a' / mê ge' s̄̄n-bo'Jo'-se'-tiēn, ziẁ ià̀ cue'-lá sờ-cù cie' lén / ỳ-zê be' miên / lién-sì

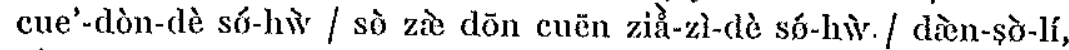
tẳ zuè pà hón-se', hô-guān, dà-đlè sēn-in, sô-î lén-mén mê ge'

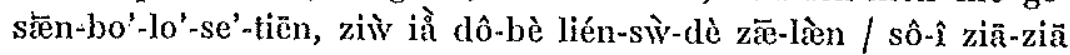
dū bâ mén zîn-bè-lā, zè mén-sàn ho' cián-sàn dū tie'-cî hón zồ-tẃ, cý̛n-ziā dū tuón-zỳ zè ie'-cî hô-pén, dà fàn-pà̀-zọ' láe dî-ỳ lién-sî, ziẁ sò sổ lién-sw zièn-dằ hón-se', hô-guãn $\hat{y}$ dà-dè sēn, bièn huè lie'-ke' zīn-zŵ̀, á (ér) lén-mén lí zie'-cố pă-gò-liââ ze'-gì láen-gurēn / dì à (c̀r) tiēn ie' zầ dà-ziā zièn-liẩ mièn, dū hù-siān cìn-hò / dà-ziā dü uè bè lién-swì cie'-dià / hv̀--lì ziì̀ iên-bièn-cén gò-lién-dè fōn-so' / ze' dū sò sén-huà-dè / bî-ziằ sờ

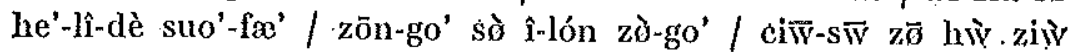
sờ hán-dōn / sò be' lén gēn-zòn / zà ze'-gì̀ só-hì-lí, sộ kōn-

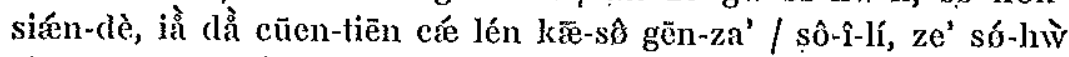

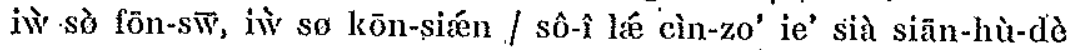
gōn-hò / lién-sẁ, sò liw fê liẃ, sô-î gû-lén zằ-zò, lién $\hat{y}$ liwí zò î̂ diên siăn-sò, lién, lá dæ̀̀-biầ sän-bo'-lo'-se'-tiēn-dè .ie'-gî̀ sóziǣen-dè mín-zố / lón-lie'-gò-lién, sie'-gù̀̀n sò hên dō / żè zōngo'-lí, dà-ż̀ siạn-tón / sièn-zà suo'-dẳ ián zד̄-lén-dè gò-lién /

cí siēn suo', læ'-ba', ziẁ sò se'-à (èr) ye', ué læ'-ye'/ læ'-bæ',

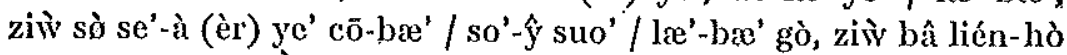
bàn / sén-mō ziạ̀ lién-hò-lí / ziẁ sò ién-háen cà / ién zī, ién ý, ién lị̂ / mò mî fên / zò diên-sīn, zēn lién-gẳ, dæ̀n cén, zò sīn î, láe ín-zie' sinn-lién-lāi/ sòn-zà̀ / sòn-zằ iŵ́ liân-tiên / à (èr) -se'-

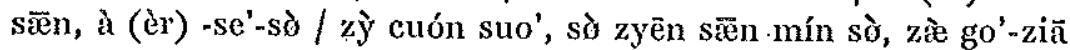

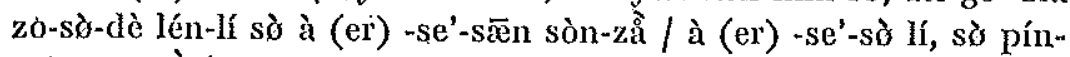
mín sòn-zà̀ /

uæn-sàn sòn-zằ-dè sǿ-hwi-lí / zæ̀-dằ zầ-tâ-sàn diĉn-cî siān zo' / fē-cán-dè gōn-zìn suo' / zầ-sén sø̀ ie'-ziä-zô zû / sàn tiēn ién hầ søे / sià zi@̀ bầ pín-iz̄en / 
cú-sie' / cú-sic'-lí, ziì sò̀ 'sǣn-se' uển-sàn / s̄̄en-se' uện-sàn-lí, ề sờ siān-clăn lón-zòn / mê ziā ze'-tiēn ụ̂̂̂n-sàn 'ià̀, có lién sè sén / ze' sò sén-mō ì-sō, zî̀ sò ie'-lién gò-cỳ-lā / iằ gên-sè sén-dè bầ-iì̀ / sô-î uên-sàn-lí, dà-ziã ià cie' lién-ià (i) -fùn / lién-ià-fàn

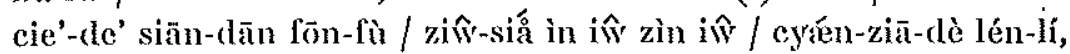
dū ż̀ zò-zè ie'-cî láe cie' / ziâ-lú î̂ ie'-gì̀ ziâa-lî-dlè lón be' zà cô dì, ho'-sò zè̀ uæ̀-mièn / be' lén lé, cie'-fàn-dè-huà / zua'-

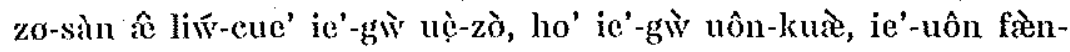

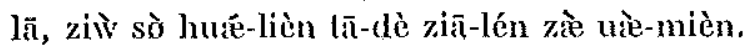

VI.

Now I will talk a little about New Year. What is in the West celebrated as New Year is by the Chinese called Yanglinián, the Solar Year. The New Year that the Chinese celcbrate is called Nonglinián, the agrarian calendar year. One of them falls before the other, but the Chinese celebrate the Nonglìnián in more impressing forms than the Yanglinián. As to the word "year", it is said according to tradition that ten thousand years ago, in the chaotic era, i.e. at the time of the first people, the year was a sort of living being, a cold-blooded animal that looked like an ox but was not so. It was called "the year monster". It had a very cruel temper. Every three hundred and sixticth day it would come out and eat people everywhere. Those who met it couldn't escape. At the time when winter and spring meet the year monster would come. But what it feared most was the colour red, firelight, and great noise. Each time it was the three hundred and sixtieth day people would of course like to escape from the dangerous ycar monster. Thereforc cvery single family locked its door carefully and glued red slips of paper on the door or the wall. And the whole family would assemble and light a fire and let ofl a lot of fireworks in order to defend themselves against the year monster and make il aware of the red colour, the fire light and the great noise. Then the year monster would immediately flee in terror and in that way pcople escaped the danger. The ncxt day everybody would congratulate each other as soon as they met in the morning. After all nobody had been eaten by the monster. Later on this has developed into the customs of New Year. This is all 
legendary. There is also a more reasonable explanation: China is an agricultural country. After the harvest the cold winter follows, when the land cannot be cultivated. At this time people are idle until spring, only then the cultivation can start. At this time of the year there is plenty of food from the harvest and people are idle and therefore they congratulate each other.

The year monster looked like an ox, but was not so. When in the old days people created the characters, the character for year therefore had a certain rescmblance to the character for ox, and the character for year represented the name of a period of three hundred and sixly days.

There are a lot of New Years' customs. They are very much the same all over China. Now I'll tell a little about the New Year in Yangzhou.

In the first place there is "la ba" : the twelfth month is called "lā yuè". "Lā bă" is then the cighth of the twclfth month. The proverb says: When "lā bä" is gone we must make things for New Year's! What kind of things are these? It is salt pickles, salted chicken, salted fish, salt meat, ground rice. We make delicacies and steamed New Year cakes. We brush the old clothes and make new clothes to welcome the New Year.

"Sòng zào" (to see the kitchen god off), "sòng zào" lasts for" two days, the 23rd and 24th. According to tradition it is the offficials on the 23rd and the people on the 24th. Those who work in the administration of the state see the kitchen god of on the 23rd. The 24th the ordinary people see him off.

In the evoning when the kitchen god is seen off, perfumed candles are lit on the kitchen range and people say very solemnly, "'The kitchen god is master of the whole family. If he speals well of us when he aseends to heaven we can preserve peace here below on the earth."

"Chñ xi" (New Year's eve). It is on the evening of the 30th. On the evening of the 30 th it is rather impressive too. This evening every family usually says good-bye to the year and thanks the gods. What does that mean? It means that when a year has passed people want to show their gratitude to the gods for their protection, and so everybody usually has a New Year's evening meal. At this New Year's evening meal we eat rather sumptuously. 
Wine and delicious food are plentiful. Everybody in the family sits together and eat. If one of the family members is not present, but far away and cannot attend the meal we leave an empty chair for him at the table or a bowl and a pair of chopsticks, a bowl of food. That is because we want to remember that one of the family members is abroad.

\section{References}

Bloch, B. and Trager, G. L.: Outline of linguistic analysis. Linguistic Society of America. Baltimore (1942).

Chao, Y.R.: The non-uniqueness of phonemic solutions of phonetic systems. Bulletin of the Institute of History and Philology Academia Sinica, vol, IV,4 (1934).

Chao, Y. R.: A grammar of spoken Chinese. Berkeley (1968).

Ding \& Li: Hanyu fangyan diaocha jianbiao. Peking (1956).

Egerod, Søren: Distinctive features and phonological reconstructions. Journal of the American Oriental Society, vol, 90 (1970).

Egerod, Soren: L'état actuel des études sur la langue chinoise. Bulletin de la société de linguistique de Paris, vol, 66 (1971).

Fischer-Jorgensen, Eli: Almen fonetik. Kobenhavn (1962, genoptr. 1971).

Giles, H. A.: A Chinese English Dictionary. London (1912).

Hanyu fangyan cihui. Wenzi gaige chubanshe. Peking (1964).

Hartmann, L. M.: The segmental phonemes of the Peiping dialect. Language, 20,1 (1944).

Henme, Henry: Sathewkok Hakka Phonology. Norsk tidskrift for sprogvidenskap, vol. $\mathrm{XX}(1964)$.

Karlgren, Bernhard: Etudes sur la phonologie Chinoise. Archives d'études orientales, vol. 15,1-4. Paris (1915-24).

Kratochvil, Paul: The Chinese language today. London (1968).

Kratochvil, Paul: An experiment in the perception of Peking dialect tones. A symposium on Chinese grammar. Scandinavian Institute of Asian studies, Monograph series nr, 6. Lund (1971).

Martinet, A.: Éléments de linguistique générale. Paris (1967).

Rygalof, Alexis: Absence de distinction tonale dans un dialecte chinois. Bulletin de la société de linguistique de Paris, vol. 60 (1965).

Trubetzkoy, N. S.: Grundzüge der Phonologie. Göttingen (1958).

Wang Nianfang: Yangzhou fangyan. Fangyan he putonghua congkan, vol. II. Peking (1959).

Wang Shihua: Yangzhouhua yinxi. Kexue chubanshe. Peking (1959).

Yuan Jiahua: Hanyu fangyan gaiyao. Peking (1960). 